\title{
Solar district heating and cooling: A review
}

Perez-Mora, Nicolas; Bava, Federico; Andersen, Martin; Bales, Chris; Lennermo, Gunnar; Nielsen, Christian; Furbo, Simon; Martínez-Moll, Víctor

Published in:

International Journal of Energy Research

Link to article, DOI:

10.1002/er.3888

Publication date:

2018

Document Version

Peer reviewed version

Link back to DTU Orbit

Citation (APA):

Perez-Mora, N., Bava, F., Andersen, M., Bales, C., Lennermo, G., Nielsen, C., Furbo, S., \& Martínez-Moll, V. (2018). Solar district heating and cooling: A review. International Journal of Energy Research, 42(4), 1419-1441. https://doi.org/10.1002/er.3888

\section{General rights}

Copyright and moral rights for the publications made accessible in the public portal are retained by the authors and/or other copyright owners and it is a condition of accessing publications that users recognise and abide by the legal requirements associated with these rights.

- Users may download and print one copy of any publication from the public portal for the purpose of private study or research.

- You may not further distribute the material or use it for any profit-making activity or commercial gain

- You may freely distribute the URL identifying the publication in the public portal

If you believe that this document breaches copyright please contact us providing details, and we will remove access to the work immediately and investigate your claim. 


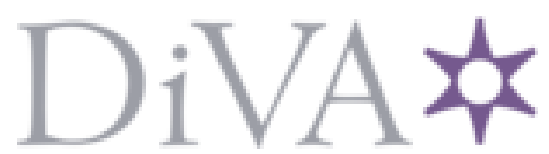

http://www.diva-portal.org

\section{Postprint}

This is the accepted version of a paper published in International journal of energy research (Print). This paper has been peer-reviewed but does not include the final publisher proof-corrections or journal pagination.

Citation for the original published paper (version of record):

Perez de la Mora, N., Bava, F., Andersen, M., Bales, C., Lennermo, G. et al. (2017)

Solar district heating and cooling: A review.

International journal of energy research (Print), : 1-23

https://doi.org/10.1002/er.3888

Access to the published version may require subscription.

N.B. When citing this work, cite the original published paper.

Permanent link to this version:

http://urn.kb.se/resolve?urn=urn:nbn:se:du-26491 


\section{Solar district heating and cooling: a review}

2 This is the peer reviewed version of the following article: "Perez-Mora N, Bava F,

3 Andersen $M$, et al. Solar district heating and cooling: A review. Int $J$ Energy Res. 2017;1-

4 23." which has been published in final form at DOI: 10.1002/er.3888. This article may be

5 used for non-commercial purposes in accordance with Wiley Terms and Conditions for

6 Self-Archiving.

7 Abbreviations

8 CES Cold Energy Storage

9 CHP Combined Heat \& Power

10 COP Coefficient of Performance

11 DC District Cooling System

12 DH District Heating

13 DHW Domestic Hot Water

14 DS Diurnal Storage

15 ESCo Energy Service Company

16 HES Heat Energy Storage

17 LCOH Levelised Cost Of Heat

18 R Return

19 S Supply

20 SBH Solar Block Heating

21 SDH Solar District Heating

22 SH Space Heating

23 ST Solar Thermal

24 SS Seasonal Storage

\section{Abstract}

Both district heating and solar collector systems have been known and implemented for many years. However, the combination of the two, with solar collectors supplying heat to the district heating network, is relatively new and no comprehensive review of scientific publications on this topic could be found. Thus, this paper summarises the literature available on solar district heating, and presents the state of the art and real experiences in this field. Given the lack of a generally accepted convention on the classification of solar district heating systems, this paper distinguishes centralized and decentralized solar district heating as well as block heating. For the different technologies, the paper describes commonly adopted control strategies, system configurations, types of installation and integration. Real-world examples are also given, to provide a more detailed insight into how solar thermal technology can be integrated with district heating. Solar thermal technology combined with thermally driven chillers to provide cooling for cooling networks is also included in this paper. In order for a technology to spread successfully, not only technical but also economic issues need to be tackled. Hence, the paper identifies and describes different types of ownership and financing schemes currently used in this field. 


\section{INTRODUCTION}

District heating (DH) has been used as an efficient method to generate and distribute heat commercially for many years now. The world's oldest operational DH system is located in Chaudes-Aigues, France. It was put in operation in the $14^{\text {th }}$ century, utilizing geothermally heated water. However, the first commercial system was developed in Lockport (USA) in 1877, utilizing steam as a heat carrier [1]. The first DH systems in Europe and Russia were installed during the 1920s and '30s, all with the aim of reducing the fuel demand and delivering heat more efficiently. This aim was further emphasized by including DH in the new national energy policies adopted by many countries during the oil crises in the '70s [2]. Nowadays, around $9 \%$ of the total heating needs in Europe are supplied by community and district heating systems [4].

On the other hand, the networks used to transport cooling are known as District Cooling systems (DC). The first known DC was installed in Denver, Colorado (USA) in 1889. Currently DC are well established in North America and the number of systems is increasing in Europe [3].

Similarly, solar energy has been harnessed to provide heat mainly for hot water and space heating for a long time. However, the combination of the two, using solar collectors to provide heat into a DH network is relatively new and has been demostrated sucessfully [5]. The first ST plants for DH date back to the late 1970s in Sweden. Since then, others plants have been installed mainly in Denmark, Germany, Austria and Sweden [6].

After a few decades of development and demonstration propelled by incentives [7], solar thermal has now become fully commercial without subsidies in Denmark [8]. Over the years, a number of scientific publications have dealt with this topic and, since 2009, the EU projects SDHtake-off, SDHplus and SDHp2m have promoted the spread of this technology, leading to a comprehensive set of guidelines and a website. In addition, there are and have been expert groups within the International Energy Agency Solar Heating and Cooling Programme dealing with this topic, e.g. Task 45 (2011-14), Task 55 (2016-20).

Heller [9] reviewed 15 years of R\&D for central solar heating in Denmark. Likewise, in [10] a review of solar-assisted district heating plants in Germany is carried out and in [11] the project Solarthermie-2000 is reviewed. Additionally in [12,13] the penetration of solar district heating in Finland under different conditions is studied. Solar heating and cooling systems with borehole thermal energy storage was recently addressed and reviewed in [14]. Despite the scientific dissemination aforementioned, there is no comprehensive review of scientific publications dealing specifically with the integration of solar thermal energy in district networks. The last attempts to review solar thermal assisted district heating plants were made several years ago and the scope of all them is limited.

Thus, the main objective of this paper is to provide a comprehensive review of the body of literature available for the use of the solar thermal (ST) energy in DH networks. The paper 
presents an overview of solar district heating and cooling separated into four different types of system. These installations have in common the harvest of solar thermal energy with solar collectors and the connection to a thermal district network to deliver that energy to the load. The paper addresses centralized and decentralized SDH, block heating and solar district cooling systems including as well their control and integration.

This work considers solar collectors and energy storage as the two main elements in a solar district network system. Thus, the two main types of mounting for the solar collector field are discussed in this work. In the same way, the alternatives of energy storage are explained along with their main features.

The paper starts with a general overview of SDH itself addressing the history of the use of heat in DH networks, introducing the background in solar thermal use in DH as well as defining and describing the typologies for different types of systems. There are then chapters on District Heating (with both centralized and decentralized collector fields), Block Heating and District Cooling, each with an example to give a more detailed insight into state-of-the-art systems and technology. The two main components in the systems, collectors and storage, are dealt with in separate chapters before other aspects and trends are discussed.

\section{GENERAL OVERVIEW OF SDH}

\subsection{District Heating}

Fundamentally, the underlying idea of the DH concept is to recycle heat that would otherwise go to waste, enabling a more efficient use of primary energy and hence, natural resources. For this reason, countries (e.g. Sweden and Germany) that have energy-intensive industries based on processes like metallurgy, petroleum and paper production have traditionally had strong ties to DH. Likewise, countries (e.g. Denmark and Finland) that traditionally have been dependent on fossil-fuel imports have developed equally strong bonds with $\mathrm{DH}$.

Geographically, DH systems are most widespread in the northern hemisphere, predominantly (descending order) in Europe (northern and eastern part), Russia, China and North America. Countries like Denmark, Sweden, Finland together with Poland and the Baltic states have the largest market shares (>40\%). Eastern European countries generally have many systems, due to the influence of the former Soviet Union, where DH was under development early as part of the planned economies.

Common for all types of DH networks is that they require some way of transferring heat between distribution network and consumer. Substations (hydraulic equivalents of electric transformers in electricity grids) contain heat exchangers and other hydraulic components used to isolate the consumer from the heat distribution network. In this way, energy (heat) can be transformed from a higher exergetic level to a lower level, usually by reducing temperature and other related parameters. The efficiency of the heat transfer is dependent on the substation design as well as difference between supply and return temperatures $(\Delta \mathrm{T})$. Modern substation technology is designed for annual supply/return temperatures of $69^{\circ} \mathrm{C} / 34^{\circ} \mathrm{C}\left(\Delta \mathrm{T}=35^{\circ} \mathrm{C}\right)$, and modern DH systems are so far able to work within $+5{ }^{\circ} \mathrm{C}$ of these temperatures [16].

The operating temperatures of DH networks are usually part of the national regulations and design guidelines, and thus may vary from country to country. An overview of some national design temperatures is given in Table 1 [17]: 
129 Table 1. Overview of some example national design temperatures for heating networks.

\begin{tabular}{lccc}
\hline & \multicolumn{3}{c}{ Temperatures $\left[{ }^{\circ} \mathbf{C}\right]$} \\
Country & Supply & Return & DHW \\
Denmark & 70 & 40 & $<60$ \\
Finland & 70 & 40 & 55 \\
Korea & 70 & 50 & 55 \\
Romania & 95 & 75 & - \\
Russia & 95 & 75 & 50 \\
United Kingdom & 82 & 70 & 65 \\
Poland & 85 & 71 & 55 \\
Germany & 80 & 60 & 55 \\
\hline
\end{tabular}

130

131

132

133

134

135

136

137

138

139

140

141

142

143

144

145

146

147

148

149

150

151

\subsection{Background}

For reasons of natural resource depletion, environmental protection, energy security and longterm economics, many governments have set goals for increasing the contribution of renewable energy sources to the national demand. In Europe, space heating (SH) and domestic hot water (DHW) account for about $80 \%$ of the energy needs of residential buildings [18]. As the temperatures required for these purposes are relatively low, there is a huge potential in exploiting solar energy through solar collectors. ST technology is widespread in the single-family house sector, while larger installations for DH are still rare, except for a few countries. Presently, large solar collector systems (>350 kWth) represent approximately 1\% of the market [19]. Nevertheless, increasing the installation size can be advantageous, as this usually leads to an enhancement of the performance and a decrease of the investment cost per unit area.

A prerequisite for a large solar collector field is a DH network, which functions as a heat sink with almost infinite capacity, where the thermal energy can be discharged. A key role for the successful integration of solar heat with DH is played by the DH operating temperatures. Both supply and return temperature should be as low as possible, so that the solar collectors operate at higher efficiency and heat losses from the DH network are reduced.

147 Figure 1 shows the historical evolution of the number of installed solar heating plants for DH applications. Currently there are approximately $5000 \mathrm{DH}$ systems in operation in Europe, supplying $10 \%$ of the total heat demand [20], but only about 150 solar district heating (SDH) systems [21], most of which have solar fractions no larger than $20 \%$. The European Union has set a target of $1 \%$ solar fraction in DH by 2020 and of $5 \%$ by 2050 [22]. 


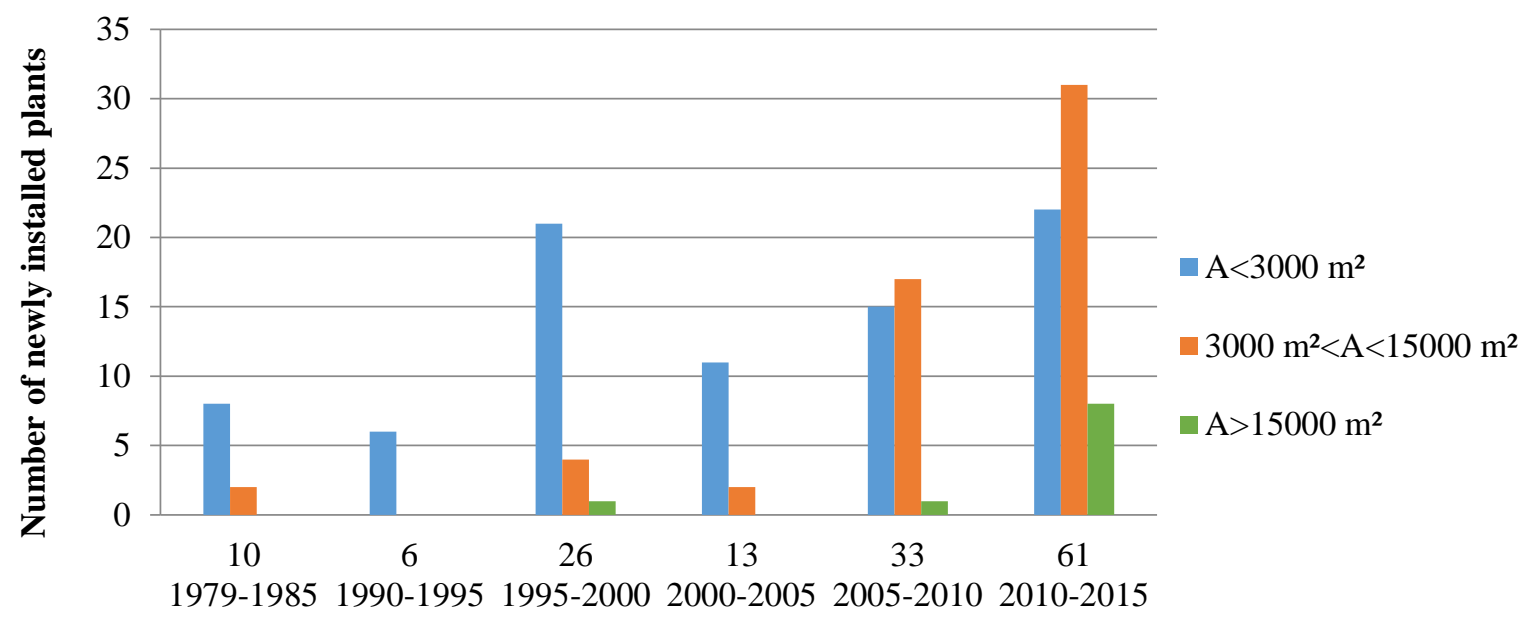

152

Year

Figure 1: Historical evolution of the number of newly installed solar heating plants in Europe. The plants are grouped according to their aperture area. The total number of newly installed plants is indicated above each time period [23].

Denmark is currently the frontrunner in the field of SDH with 79 plants installed at the end of 2015 [24]. In other European countries, much smaller markets exist. Sweden was the pioneer in the early years of development of SDH (1979-1995), when it installed 12 of its current 23 plants [23,24]. Austria has seen a rapid development in SDH in the last ten years and is now the third country for installed collector area [23] with 28 systems larger than $500 \mathrm{~m}^{2}$ supplying DH or block heating networks [24]. In Germany, 25 plants are currently in operation [24]. Of these, many were installed in the period 1995-2005, stimulated by the 10year long governmental programme Solarthermie-2000, launched in 1993 [11]. Smaller markets in terms of installed collector area exist in Spain (16 plants), France (15), Greece (14), Poland (14) and Switzerland (9) [24].

Most large scale solar applications are connected to DH systems, but there is an increasing number of solar cooling plants supplying with chilled water instead of hot water [25], but most of these are not district cooling networks with several customers.

\subsection{System typologies}

There are three parts to consider when including ST into a system:

- the solar circuit itself (collector, piping, pump, valves and expansion vessel),

- the integration of the solar circuit into the overall system and

- the flow control in the solar circuit and the control of the rest of the DH system.

The solar circuit itself can, in principle, have the same design for all types of system typology for $\mathrm{DH}$, but practical details vary depending on whether the collector is ground or roof mounted. The main differences between typologies are in system integration, and many different options have been studied. The flow control in the collector circuit is dependent on this system integration, but only two strategies are used in practice: constant, normally high flow rate to maximize solar gain; matched flow so that the collector field supplies a desired temperature, normally the supply temperature in the DH network.

If the ST system will only supply a small part of the DH demand, then the system integration is relatively simple, no matter what the system typology is. With very low solar fraction, 
$<50 \%$ of the daily summer demand in the DH network on a cloudless day, no storage is required for the solar heat other than in the DH network itself [26]. With higher solar fractions, storage is required somewhere in the system. The choice is centralized or distributed storage, leading to different system typologies and a need for an overall plan for the whole DH network. In this article, three different typologies are distinguished (Figure 2).

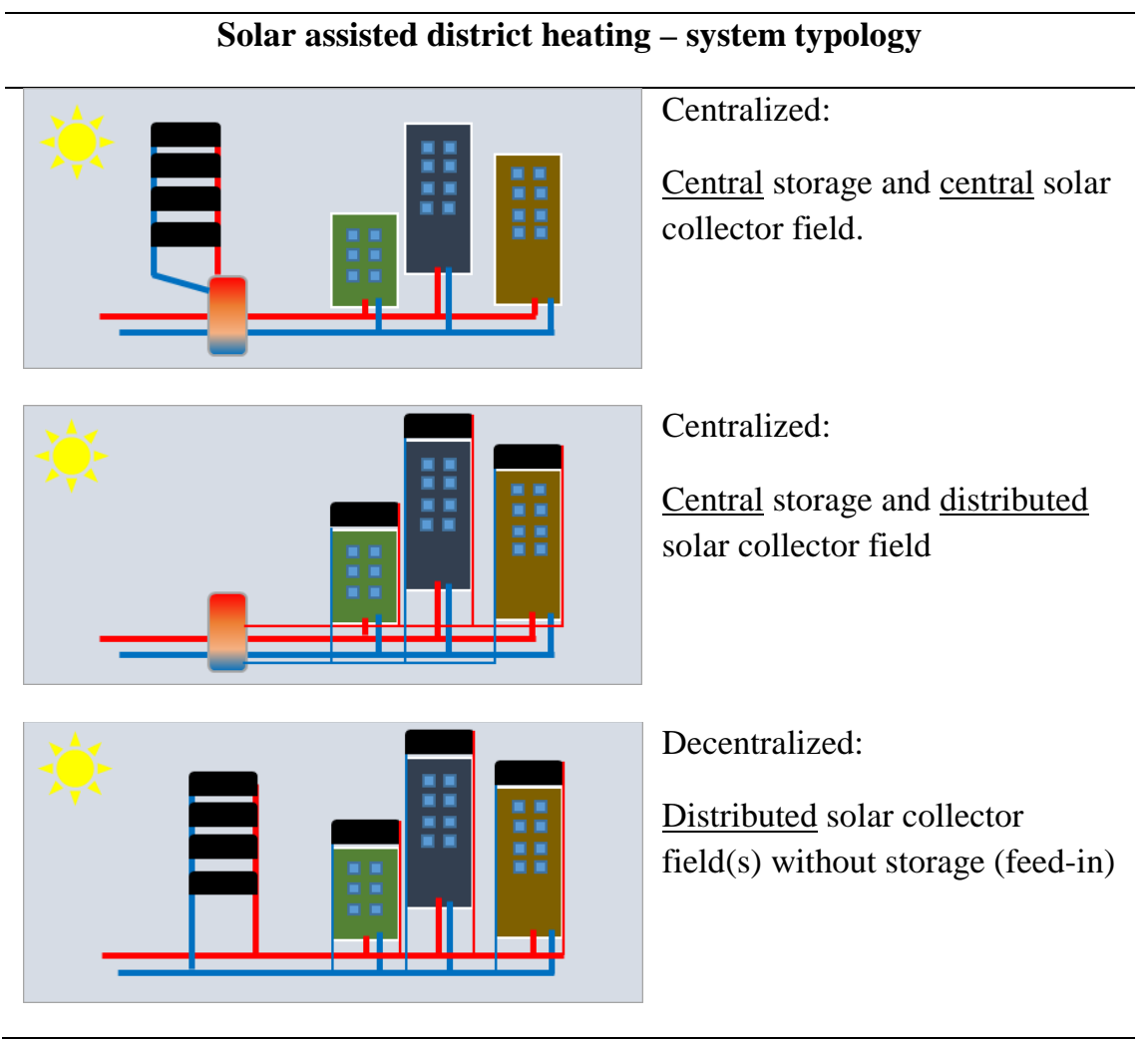

Figure 2: Overview of different system typologies in SDH systems

190

The following chapters will cover:

- Centralized systems with central storage and a central (usually ground-mounted) solar collector field connected to the network supply.

- Decentralized systems without storage and distributed solar collector field(s) feeding into the network supply pipe. These systems usually cover a smaller solar fraction and are typically mounted on available roof-space, although they can be ground-mounted as well.

Decentralized systems may also feature distributed storage(s) and distributed solar collector field(s) connected to the network load side. However, these systems are not treated in this article.

- Block heating systems are treated in this article as smaller DH systems. The solar integration varies with system concept and may consist of different typologies: centralized storage and collector field, centralized storage and distributed collector field or mixed typologies, where there can be both centralized and distributed collector fields and storage. 


\section{CENTRALIZED SDH SYSTEMS}

In centralized SDH systems, the solar collector field is usually installed close to the main DH plant, which hosts the auxiliary energy system (Figure 3). The European market of centralized SDH systems is dominated by ground-mounted flat plate collectors, which represents more than $90 \%$ of the total area [23,27]. Unlike block heating systems, most solar collector fields for centralized SDH are added to existing DH networks, in order to reduce the use of conventional fuels in the main heating plant.

From a technical point of view, solar heat can be combined with all other fuels for DH, but some of them are more suitable for environmental and economic reasons [28]. The auxiliary energy system often relies on natural gas (CHP plants or boilers) or biomass [27,29,30], and is turned on when solar energy cannot completely cover the heat demand. The solar collector field is usually installed in parallel with the auxiliary energy system (Figure 4). In case of high solar radiation, the collector field provides the entire temperature rise required by the $\mathrm{DH}$ network. If the solar radiation is not sufficient, the warm water from the ST system cannot be injected directly into the DH network. In this case, the auxiliary energy system supplies additional energy to increase the fluid temperature to the DH supply temperature. The heating plant is equipped with a storage, which can store heat from the auxiliary energy system and the solar collector field. The size of the storage plays an important role in the solar fraction that the system can achieve (see Section 8).

Large solar heating systems with capacity larger than $350 \mathrm{~kW}$ represent a very small portion (about 1\%) of the European market for solar heat, which is about 2-3 $\mathrm{GW}_{\text {th }}$ per year [19]. Denmark is the leading country in this sector [8] with $77 \%$ of the collector area installed in the European solar heating plants at the end of 2015 [24]. With about 800,000 $\mathrm{m}^{2}$ of collectors and 79 plants in operation at the end of 2015 [24], this country is a unique example for a mature and commercial SDH market without subsidies. A key role in this development has been played by the widespread use of $\mathrm{DH}$, which supply about $60 \%$ of the heating demand of buildings [8], and high taxation on fossil fuels [31].

The size of the installations varies significantly depending on the $\mathrm{DH}$ load, aimed solar fraction, presence of seasonal storage and economic considerations. Collector fields with nominal capacity between $700 \mathrm{~kW}$ and $50 \mathrm{MW}$ are installed in Europe [23,27].

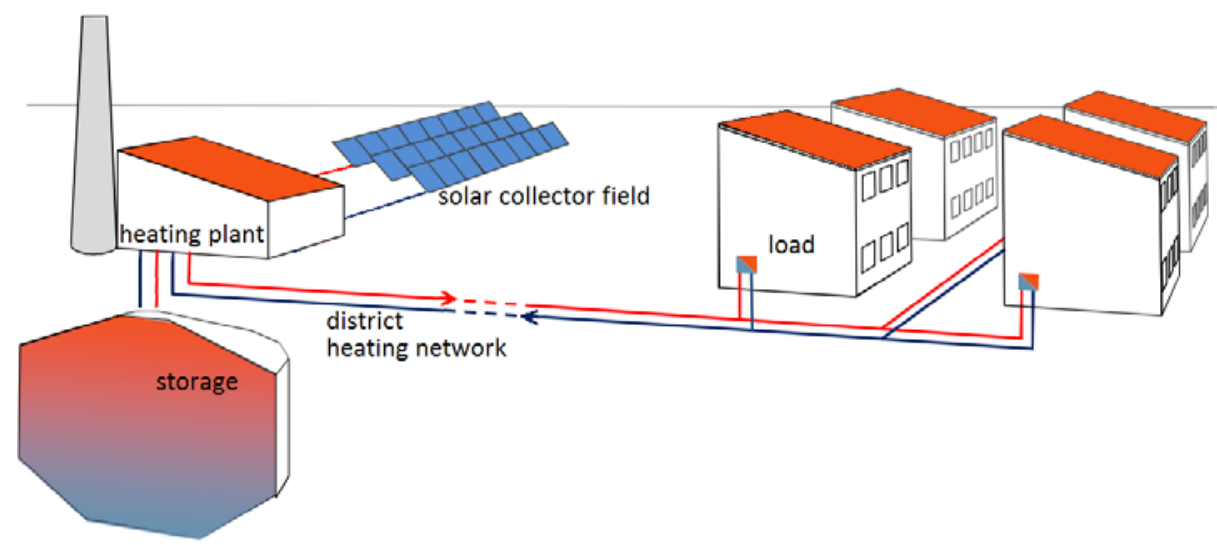

Figure 3: Scheme of a centralized SDH network at a DH plant (adapted from Solites [32]). 


\subsubsection{System description}

An example of centralized SDH system is given by the Danish plant in Braedstrup. This has a yearly heat production of 40-45 GWh and supplies SH and DHW to 1400 buildings (290,000 $\mathrm{m}^{2}$ ), through a $49 \mathrm{~km}$ long network. Typical supply and return temperatures are $75{ }^{\circ} \mathrm{C}$ and 40 ${ }^{\circ} \mathrm{C}$ respectively. The original plant, consisting of two gas fired CHP engines, two gas boilers and a $2000 \mathrm{~m}^{3}$ tank, was expanded in 2007 with $8000 \mathrm{~m}^{2}$ solar collector field. In 2012, other $10600 \mathrm{~m}^{2}$ collectors were installed, together with a $5000 \mathrm{~m}^{3}$ buffer tank, a $19000 \mathrm{~m}^{3}$ seasonal borehole storage (5000 $\mathrm{m}^{3}$ water equivalent), 1.2 $\mathrm{MW}_{\text {heat }}$ heat pump and 10 MW electric boiler [33]. A further expansion of the collector field, borehole storage and heat pump capacity is planned, to completely replace the use of natural gas in the future. Figure 4 shows a schematic of the current plant. The control strategy of the entire plant aims at minimizing the heat production cost and maximizing the income from selling the electricity produced by the gas engines. Consequently, the ST system has the highest priority of operation whenever possible, as it delivers almost free heat. Gas engines are run when the electricity prices make their operation profitable. The plant is run differently depending on the season. In winter, the return of the DH network is supplied directly to the large tank, while the small tank is used to discharge the borehole storage. In spring, the large tank is progressively charged and, when it is full, the plant switches to "summer mode" and the DH return goes into the small tank. When the large tank is more than $50 \%$ charged, some of its water is extracted and sent to the borehole storage to charge it and then returned to the connection between the two tanks. The heat pump and the electric boiler are turned on when the electricity price is very low. When it is not suitable to use the above mentioned technologies or they cannot cover the heat demand, gas boilers are turned on.

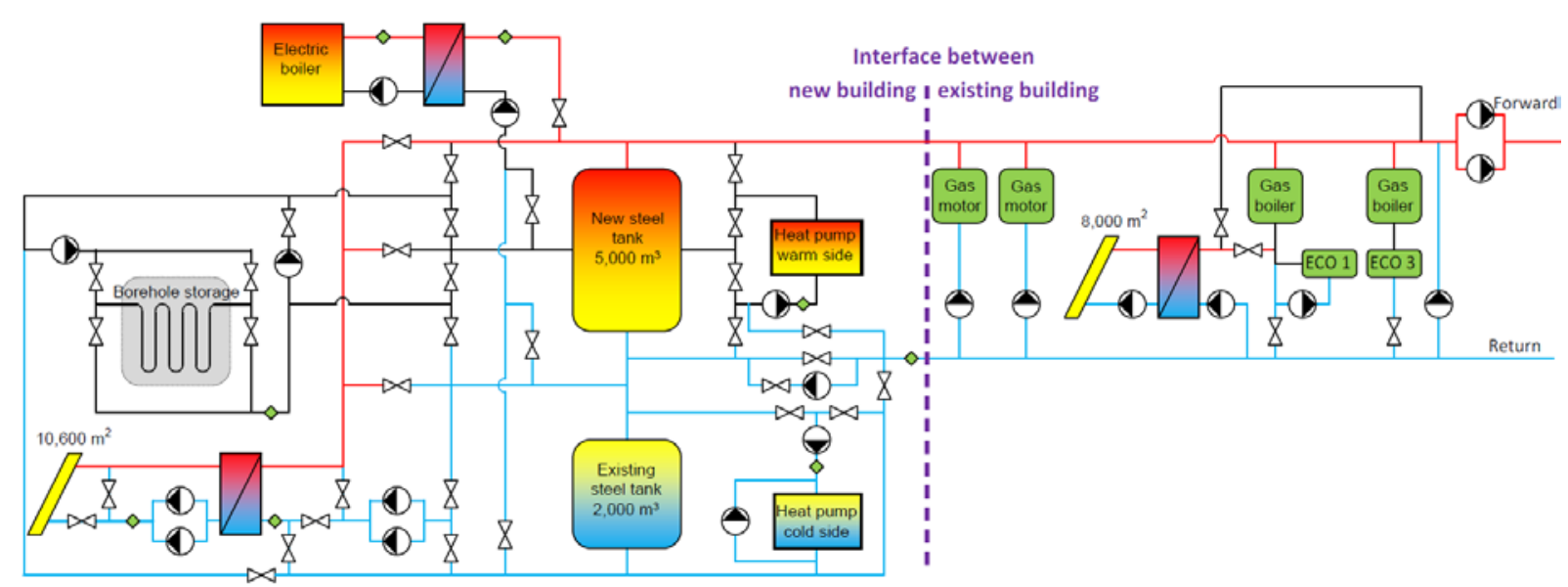

Figure 4: Principle diagram of Braedstrup heating plant [33].

Monitoring data of the different plant components from 2012 were made available by PlanEnergi [33]. It must be noted that the new solar collector field was put into operation only in April 2012 and the borehole storage in May 2012. Of the 40 GWh delivered, 15\% were provided by the solar collector field, $58 \%$ by the gas boilers, $20 \%$ by waste heat of the gas engines and $7 \%$ by the electric boiler. Negligible contribution came from the heat pump and borehole storage, most likely because a borehole storage needs a couple of years of charging 
before being able to release useful energy. In the months of July and August, solar energy

272 covered more than $70 \%$ of the total heat demand and the gas boilers were barely used. The

273 yearly energy output of the solar collector fields was $435 \mathrm{kWh} / \mathrm{m}^{2}$ and had an average

274 efficiency of 36\% [33].

275 3.1.2. Economy

276 The costs of the main components added during the extension in 2012 are shown in Table 2.

277 The collector field represented the main voice of expense, with a specific cost of about 300

$278 € / \mathrm{m}^{2}$ including land and pipes. The borehole storage had a cost of about $50 €$ per cubic meter

279 of water equivalent.

280

281 Table 2: Main cost for the extension of Braedstrup heating plant in 2012 [33].

\begin{tabular}{lr}
\hline Component & Cost [k€] \\
\hline Solar plant, transmission pipe and tank connection & 2933 \\
Land & 240 \\
Piping of the water loop side & 158 \\
Borehole storage (drilling, pipes, lid) & 262 \\
Test drilling and laboratory (borehole prestudy) & 37 \\
Heat pump & 101 \\
Accumulation tank & 96 \\
Electric boiler + connections & 663 \\
Measuring equipment & 37 \\
Control system & 445 \\
Total & $\mathbf{4 9 7 2}$ \\
\hline
\end{tabular}

Based on the decrease in the average installation price in the last years (see Figure 13), the cost of a solar collector field with similar characteristics to Brædstrup can be expected to be $10 \%$ - 15\% lower (specific cost of $240 € / \mathrm{m} 2$ [34]) if installed in 2016. In addition, the borehole storage would likely have a lower cost due to experience acquired with this type of installation. However, precise costs cannot be estimated because of the lack of new installations of this type in the last years.

\section{DECENTRALIZED (FEED-IN) COLLECTOR FIELDS}

In this article a ST system that is connected to a DH network outside the main heating plant is classified as a decentralized system, even when the distance from the feed-in point to the main pumps in the DH system is only some meters [35]. The collector field is normally roofmounted, but systems with ground-mounted collectors also exist. Nearly all decentralized ST systems are connected to existing DH networks.

Unlike centralized system, decentralized plants are often, but not necessarily, located where there is a load and thus an existing DH substation.

Decentralized systems can be connected to the DH network in different ways (Figure 5). The most common connection is Return/Supply (R/S), where water from the return DH pipe is heated up and pumped back into the supply pipe. If there is an existing substation at the feedin site, no new service pipes to the DH network are required. The flow in the service pipes between the substations and the DH network can flow in both directions, the direction being 
dependent on the heat balance between the solar heat feed-in and the required heat at the load substation.

If a Return/Return (R/R) feed-in system is connected to the DH network at the same place as a substation, the normal supply and return service pipes are not sufficient. As shown in Figure 5 , a third pipe, taking the solar heated water back to the $\mathrm{DH}$ return pipe, is required. The R/R connection also increases the return temperature of the network, which is undesirable in many DH systems. If the central heating plant includes CHP, heat pumps, ST and exhaust gas condensation, the efficiency of these production units decreases if the return temperature increases. Conversely, if the central heat production unit is not affected by higher return temperatures, this issue of decreased efficiency does not occur, as long as the heat load is higher than the lowest recommended load of the heat production unit. This is one of the main reasons why the $\mathrm{R} / \mathrm{R}$ connection is less common than $\mathrm{R} / \mathrm{S}$ connection. However, the control in an $\mathrm{R} / \mathrm{R}$ connection is simpler, as it can use a constant flow rate, whereas in an R/S connection the feed-in flow rate is varied to maintain a certain supply temperature to the network, which is specified by the network operator.

Theoretically, supply/supply (S/S) and supply/return (S/R) connections are also possible, but these present some disadvantages and are only used in exceptional circumstances, such as to avoid overheating in the collector field. Hence, they are not covered in this article.

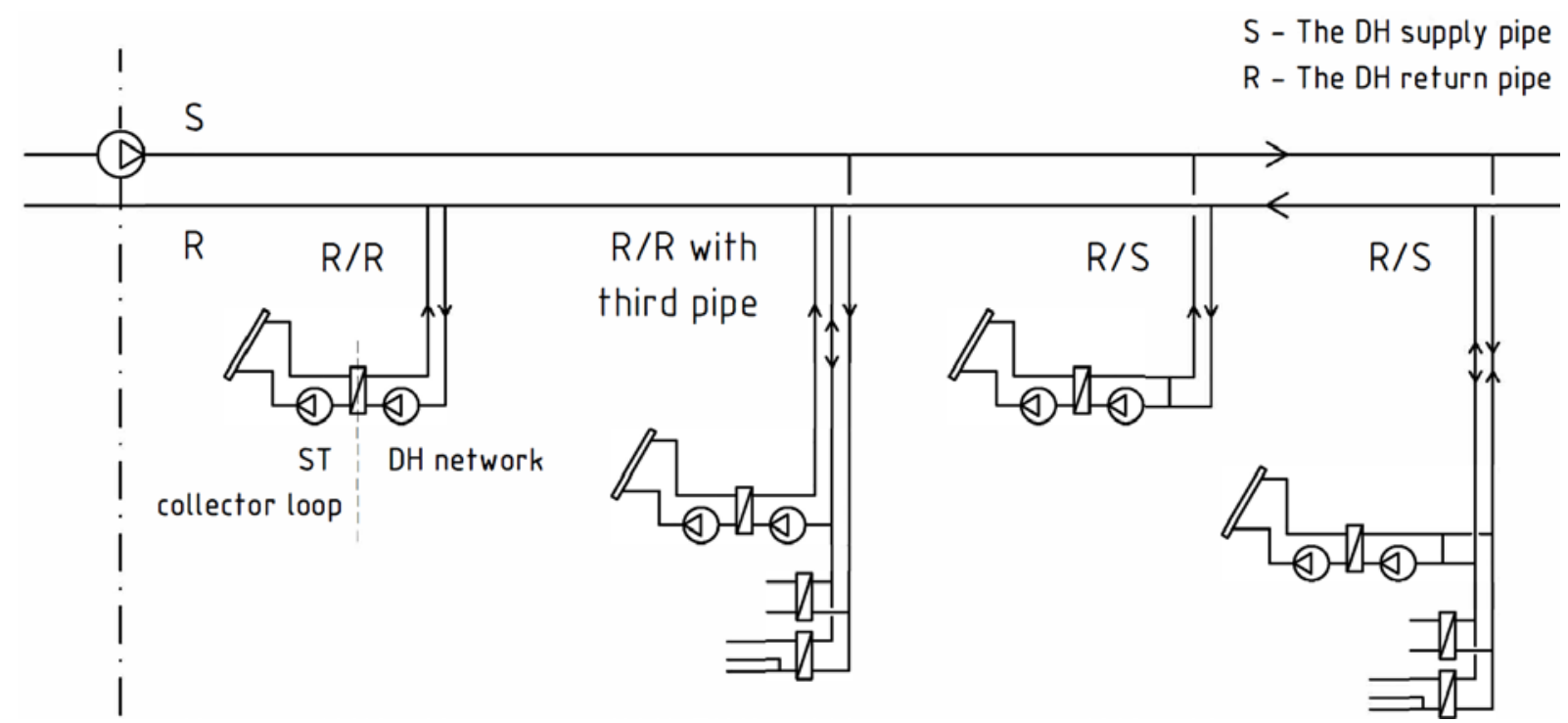

Figure 5: The most common ways to connect decentralized ST systems to the DH network.

In Sweden, the first R/S systems were built in 2000 in conjunction with the building exhibition Bo01in Malmö. Since then, around 30 R/S systems have been built in Sweden. Twenty-two of these plants, varying in size from 42 to $1128 \mathrm{~m}^{2}$ collector area, are analysed in [36]. The authors conclude that several of the plants were not performing as well as planned. Some had maintenance issues, while others had been working reliably and as expected. There were several different designs, mostly in terms of control of the temperature supplied to the DH network. Some R/S substations had been designed by consultants and built on site, while several were supplied as pre-fabricated substations, sized according to the collector area. Lennermo et al. [37] found that some of the systems had large variations of outlet temperature in the collector loop and feed-in heat power over time. The variations have also been found in 
R/S feed-in systems with heat generation systems other than solar. Flow and heat power variations in the feed-in system can cause problem in the DH network, especially if the feedin system is large. If the feed-in system is small compared to the DH system, problems are less common. The problem with temperature and heat power variations is more difficult to solve if the differential pressure is high and the feed-in flow is low or it has a large variation due to the characteristics of the heat power generation, as it is in a ST system [38]. Hassine and Eicker [39] studied R/R, R/S and S/S connections through simulation of the DH network of the Scharnhauser Park (Germany) with 584 consumers. They focused on the ST contribution and on the impact of the geographical location of the ST in the DH system on heat users, not located near the ST, and on the central plant. They conclude that the R/R connection was the most efficient option from a ST heat production point of view, but also that the S/S connection could give benefits, if the ST system was located near the edge of the network, where the supply temperature is lower compared to near the centre of the network due to heat losses. Hassine and Eicker [40] also studied control aspects of the main DH pump in a network with ST system with R/S connection. They found that pressure control using a limited number of pressure sensors was not reasonable, whereas volume control was. In Austria, the company Solid has installed large decentralized solar plants in Graz. The system at the UPC Arena consists of $1407 \mathrm{~m}^{2}$ roof-mounted flat plate collectors. These are connected to the main DH network with an R/S connection with variable speed pump and two-way valve [41]. The system at Wasserwerk Andritz has $3855 \mathrm{~m}^{2}$ ground-mounted flat plate collectors as well as a $60 \mathrm{~m}^{3}$ water storage, and is thus a decentralized system with distributed storage. The collector field is connected $\mathrm{R} / \mathrm{S}$ to the $\mathrm{DH}$ network but also in parallel to the local store and therefore supplies heat to the local buildings at the water works as well as to the DH network [42]. Based on the experience of these systems, Holter [43] claims that $100 \%$ of the summer load for the Graz DH network ( 15 MW) can be met by waste heat together with solar energy, preferably using systems like that at Wasserwerk Andritz with feed-in to the DH network as well as on site use of the solar heat.

Paulus and Papillon [44] made a techno-economic analysis of a range of substation designs based on simulations of the local load and different DH network operating temperatures. Nine different substation architectures were simulated, ranging from purely feed-in connection to combined systems with both DH feed-in and solar heat use on site with thermal storages supplying both DHW and SH. They used an R/R connection for all architectures. They conclude that low DH return temperatures favour both the efficiency of the solar plant as well as economics for all architectures. For higher return temperatures, some architectures reduce the loss of thermal efficiency of the solar field due to the higher operating temperatures. In Denmark, the focus has been on large centralized solar installation, but there are also a few decentralized plants installed. The plant at Avedøre has $750 \mathrm{~m}^{2}$ roof-mounted flat plate collectors on top of a large multifamily house with a R/S connection [45]. The plant at Herredsvej/Månepletvej in Hillerød has $3000 \mathrm{~m}^{2}$ ground-mounted flat plate collectors with $\mathrm{R} / \mathrm{S}$ connection.

\section{4.1. Example (Vislanda, Sweden)}

374 The system in Vislanda (Sweden) was installed in 2009 as a roof-integrated flat plate collector 375 field of $344 \mathrm{~m}^{2}$, located on a single building. The substation is a pre-fabricated unit with R/S 
connection where the feed-in flow is controlled by a variable speed pump and a motorized two-way valve, as shown in Figure 6 [36]. The system is owned by the housing company Allbohus, and feeds into the DH network operated by Alvesta Energi, with which Allbohus has a net-metering contract. According to Dalenbäck et al. [36], the system did not work properly during the measurement campaign in 2011-2012, but it was fixed in 2013. The authors conclude that the $\mathrm{DH}$ operating temperatures are sometimes too high, due to the nearby input of waste heat from an industrial plant into the return pipe of the DH network. This results in a relatively poor operation of the collector field.

At the time of the installation, the owner had already planned to replace the roof of the building. Thus the net costs for the system were relatively low, after subtracting the cost for a normal roof from the total investment cost [42]. The company that won the tendering contract produced large collectors, which were integrated in the roof. The total cost of the turn-key system was $178 \mathrm{k} €$ without VAT, resulting in a specific cost of $516 € / \mathrm{m}^{2}$. This value is relatively low for such a small system [42], but still much higher compared to large centralized systems in Denmark. For example, the collector field of $8000 \mathrm{~m}^{2}$ in Braedstrup (see Section 3.1.2) had a specific system cost of $300 € / \mathrm{m}^{2}$, including land and service pipes.

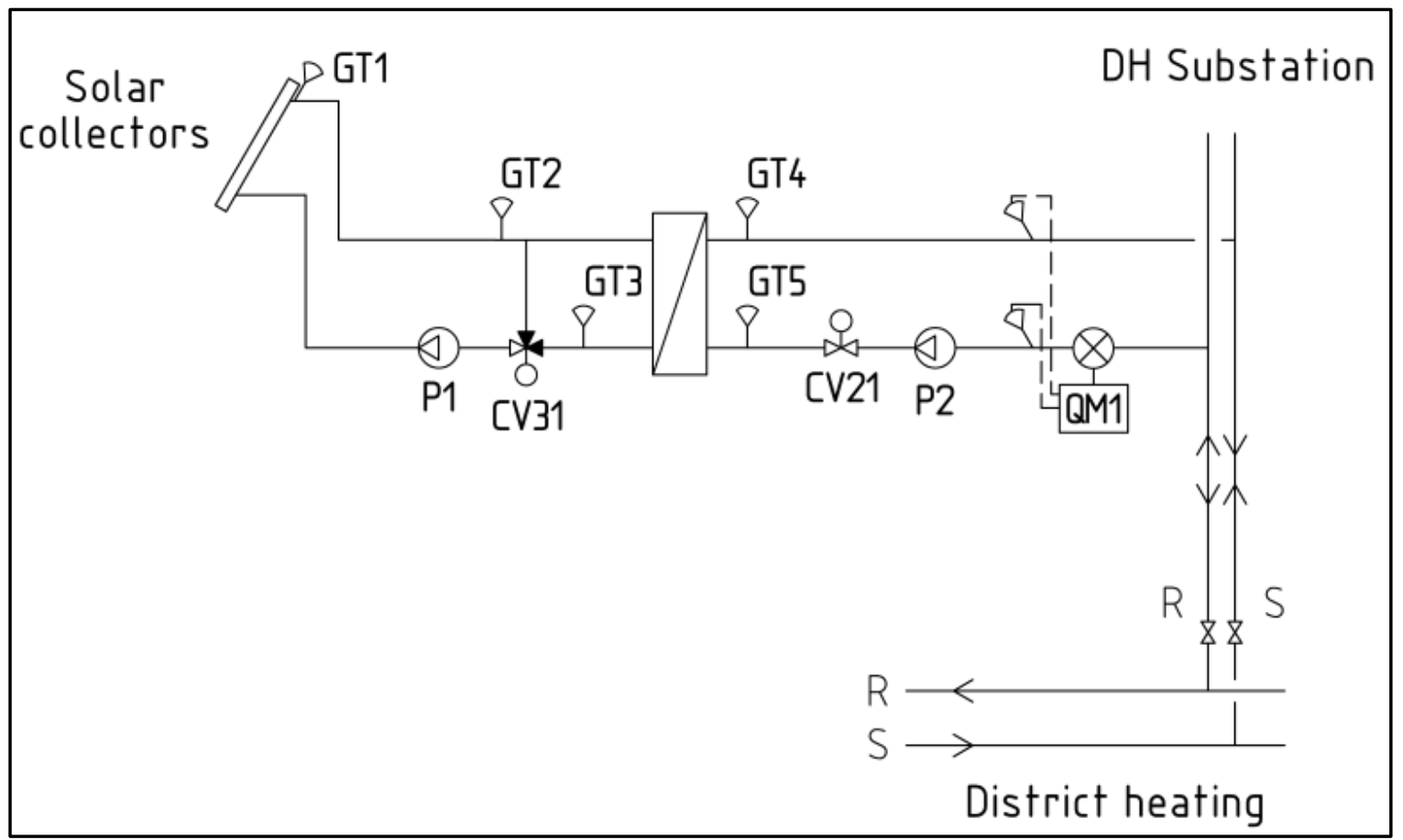

Figure 6: Schematic of the pre-fabricated R/S substation of the feed-in system in Vislanda, Sweden.

\section{BLOCK HEATING}

Block heating systems are small DH networks. The integration of a ST system into a block heating network can be a cost-effective solution, especially for new low-energy residential areas. This is why nearly all solar block heating systems are built at the same time as the buildings. Areas of around 10-100 one-family houses or up to 400 dwellings in multi-family buildings exist, such as in Friedrichshafen [46]. The typical boiler capacity in this kind of systems is between $50 \mathrm{~kW}$ and $10 \mathrm{MW}$ [47]. Normally, systems with diurnal storage have a 
design solar fraction of around $20 \%$, delivering $80 \%-100 \%$ of the DHW load in the summer months. Solar assisted block heating systems have been built for more than 30 years [48]. Studies have mainly focused on lowering the heat losses, increasing the efficiency and solar fraction of the ST system, while decreasing the costs.

In Germany, the Solarthermie-2000 program stimulated the installation of this kind of systems with different sizes. It proved to be possible to reach high solar fractions, especially using seasonal storages. Solarthermie-2000 and Solarthermie+ resulted in several reports on experiences and recommendations for solar block heating systems [11]. In order for seasonal storage to be feasible, the network should consist of at least 100 dwellings [49]. Based on TrnSys simulations, Sibbitt et al. [50] found that the most profitable solution for a smaller block heating network with seasonal storage would be:

- Individual DHW with solar heat and auxiliary heating, and

- A low temperature distribution network supplied by centralized solar panels connected to a seasonal borehole storage.

A system based on this design was built for a housing estate of 52 houses in 2007 in Drake Landing (Canada) and achieved a solar fraction higher than $90 \%$ after 5 years of operation [50].

\subsection{System Integration}

Solar block heating systems can have different integration typologies. The collectors may be located at or close to the central heating plant, but more often they are distributed on the roofs of the buildings supplied by the DH network. These distributed collector fields can either be connected to a central store or use a mixed typology with both centralized and distributed storage. As the distribution network and the collectors are normally designed and built at the same time as the buildings, it is possible to optimise the integration of the ST system. Extension of the housing area together with the network is relatively common after the main network has been installed.

Clever storage design, sizing and strategy are necessary to increase the system efficiency and ensure a stable operation. It is important to have a good coherence between solar feed-in, boiler operation and storage temperature. Accurate temperature monitoring is essential to obtain correct operation [29]. As for any ST system, one of the most important factors to obtain high efficiency is a low return temperature from the distribution network. Three different systems in Germany (Hannover, Hamburg and Steinfurt) were investigated in [51]. In all three systems, problems were found on the consumer side of the network. In all cases, it was possible to lower the network return temperature by considering better-sized components, ensuring that the installed components worked properly, and optimizing the control strategy with regard to energy efficiency.

Besides the network temperatures, other two parameters affect the network heat losses: thermal insulation of the network pipes and heat density of the network. Dahm [52] simulated different distribution networks, types of substations and house heating systems for a block heating network in Swedish conditions, using models calibrated from two networks. The study showed that the heat losses contributed very little to the annual heat cost, and that a network with higher operating temperatures (due to high temperature radiators) has similar losses compared to a network with lower operating temperature. In fact, using smaller 
diameter pipes in the DH network, when operating at higher temperatures, reduced the overall heat transfer surface. The heating system in the houses had the highest impact on the annual heat cost. Substations with local DHW storage were shown to be the least cost-effective solution.

The Swedish municipal housing company Eksta has been building solar assisted block heating systems since the 1980s, in cooperation with engineers and designers. The systems have been designed and built at the same time as the houses, and all of them have roof-mounted collectors. One of them, in Särö, includes a small seasonal water storage of $650 \mathrm{~m}^{3}$ with 750 $\mathrm{m}^{2}$ roof-integrated collectors. The design solar fraction is 35\% [53]. The heat distribution type Grudis [54] was developed to decrease the cost and have acceptable heat losses for small lowdensity networks by delivering SH using a DHW circulation loop between a substation and the houses. This type of system was used in Vallda Heberg, described in detail in Section 5.2. Delivering heat with "pulses" is another way to decrease heat losses. In this way, the DH network is used only $20 \%-50 \%$ of the time to charge distributed storages. This was successfully implemented in Hjortshøj (Denmark), where distribution losses were decreased by $20 \%-27 \%$ compared to a system with continuous flow [55]. To further decrease

462

463

464

465

466

467

468

469

470

471

472

473

474

475

476

477

478

479

480

481

482

483

484

485

486 distribution losses in the summer period, distributed solar collectors were installed for individual DHW preparation. The overall distribution losses are decreased by 50\% [55]. In this way the network can be shut off in summer, making the maintenance easier [56]. These strategies have only been tested in block heating systems, as they require specific substations for all consumers, and their implementation is only realistic in new networks.

Several piping layouts exist. The most appropriate layout depends on the properties of the heating plant and the heat density of the network. This has been investigated in Germany [57] and in Austria in the MOSOL-NET project. Based on computer models and experiences, several recommendations have been given on network design, collector positioning and optimal control [58]. The recommendations of the German and Austrian studies are rather similar, although the detailed design is very system dependent:

- six pipes (two each for DHW, SH and solar) for dense heating networks;

- four pipes (two for distribution of DHW\&SH and two for solar) for large networks, also including long-term storage;

- three pipes (two for distribution of DHW and SH, one for solar supply). The input to the collectors is taken from the distribution return pipe, while the collector outlet fluid flows into the third pipe. Obviously, the third pipe cannot use water/glycol mixture for frost protection.

Advanced control strategies can significantly increase the system efficiency. An innovative solution has been tried for a small network with low energy buildings in Gleisdorf (Austria) [59]. The network is operated 22 hours/day at $40^{\circ} \mathrm{C}$ for SH, and 2 hours during night at 65-70 ${ }^{\circ} \mathrm{C}$ to prepare DHW in decentralized hot water storage tanks.

Beckenbauer et al. [60] analysed the solar retrofitting of a block heating system, comparing different centralized and decentralized setups. Mainly due to high network return temperature, a decentralized solution with direct DHW preparation was found to be optimal for this case. 
The Vallda Heberg area, built by the housing company Eksta in Sweden, consists of 26 single-family buildings, four multifamily buildings (4 apartments per building), 6 terrace houses with in total 22 units and also a nursing home for elderly people with 64 apartments. The total heated floor area is about $14000 \mathrm{~m}^{2}$ and the measured yearly heat demand is 621 MWh [61]. A kindergarten and a few commercial buildings are planned to be added in the next future. All buildings are designed as passive houses with mechanical ventilation heat recovery, and thus the heat demand is low. In the houses, heat is supplied by floor heating in the bathrooms and an additional water/air heat exchanger in the supply air to the building.

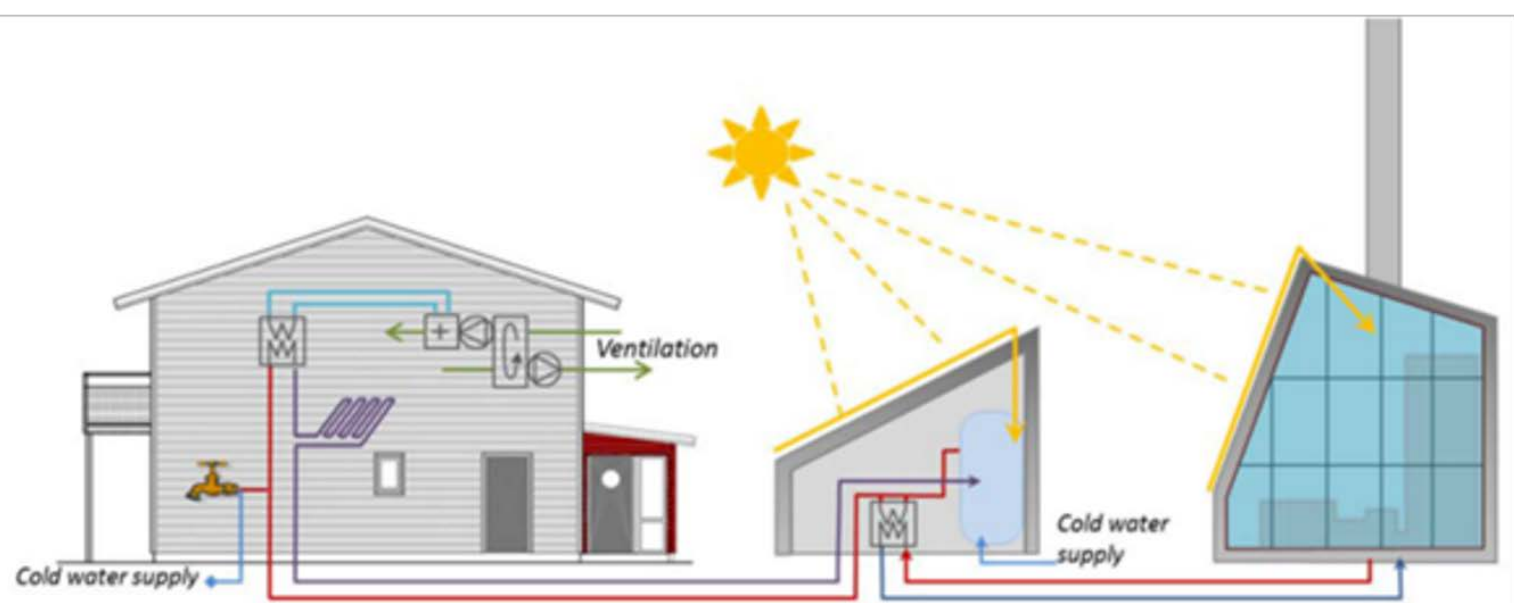

Figure 7: Partly decentralized system in Vallda Heberg showing an example house (left), example substation with roof-mounted collectors and storage (middle) as well central heating plant with rood mounted collectors (right). [Anderson/Hultmark: [61]].

The local DH system comprises a central heating plant with a $250 \mathrm{~kW}$ wood pellet boiler and four substations. Each substation supplies a part of the housing estate and is connected to its own collector array (see Figure 8). In the central heating plant and in each substation there are buffer storage tanks. There are $108 \mathrm{~m}^{2}$ evacuated tube solar collectors on the heating plant and $570 \mathrm{~m}^{2}$ flat plate roof-integrated solar collectors in connection to the substations (see Figure 7). The distribution networks from the four substations to the dwellings are of Grudis type [54], which essentially is a DHW circulation loop with direct connection to the houses. The floor heating in the houses is a part of this loop and. To avoid risk of legionella, the entire loop is maintained between $50^{\circ} \mathrm{C}$ and $60^{\circ} \mathrm{C}$. For this reason, there is no flow control in the floor heating loop. This results in a very simple and cost-effective heating system, as well as a simple distribution network with plastic pipes. However, as the buildings are passive houses, the energy density of the network is low. The authors report that the 2014 monitored data for substation 1, with $142 \mathrm{~m}^{2}$ collector area supplying 19 single family houses, show that the combined losses for the substation itself and the DHW circulation loop were $24 \%$ of the total demand (SH, DHW and losses). The specific collector yield for the collectors connected to substation 1 was $299 \mathrm{kWh} / \mathrm{m}^{2} /$ year resulting in a solar fraction of $31 \%$, with $90 \%$ of the solar heat supplied from the collectors connected to the substation and only $10 \%$ coming from the collectors at the main boiler plant. 


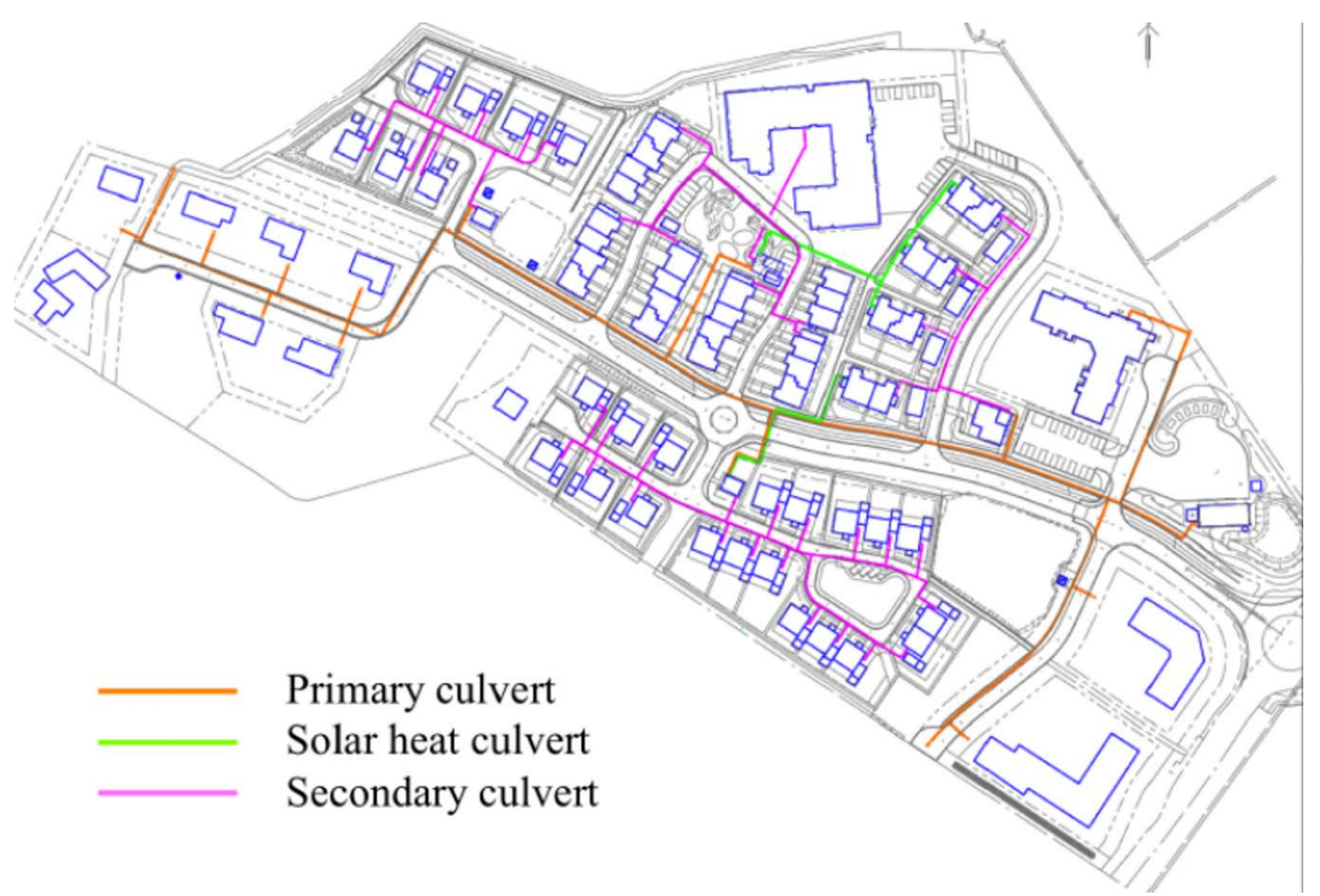

520

521

522

523

524

525

526

527

528

529

530

531

532

533

534

535

536

537

538

539

540

541

542

543

Figure 8: Vallda Heberg area with central heating plant (red oval, right), four substations (red circles),distribution pipes for heat supply (brown) and -load (violet), and solar heat (green) between the 4 multifamily buildings and substations 1 (middle, bottom) and 3 (middle, top).

\section{DISTRICT COOLING}

A district cooling system (DC) distributes chilled water in buried pipes and delivers cooling energy to the substation of the users in order to meet their cooling requirements [62]. In DC, a lower amount of energy is supplied with the same amount of liquid compared to DH due to the lower temperature difference used in DC. Usual temperate difference is about $6{ }^{\circ} \mathrm{C}$ (usually $6{ }^{\circ} \mathrm{C} / 12{ }^{\circ} \mathrm{C}$ as supply/return temperatures) or at most $8{ }^{\circ} \mathrm{C}\left(4^{\circ} \mathrm{C} / 12{ }^{\circ} \mathrm{C}\right)$ for ice based systems [17]. Consequently, DC pipes are generally larger compared to DH. A higher temperature difference may be used to lower the power consumption of the distribution pump, but this will increase the heat gains of the pipes [62,63]. It is generally recommended to find optimal supply/return temperatures in order to optimize the efficiency of the generating cooling system and of the overall DC, as wrong temperature configuration may lead to an excessive energy consumption from the cooling system [64-66].

Shimoda et al. [67] showed that DC that produce large-scale and collective cooling energy have a higher efficiency than conventional systems at individual premises. The total energy consumption of a DC may be $8 \%$ lower compared to individual systems. The current cooling demand worldwide, despite being much smaller than the heating demand, is growing exponentially. It is expected that by 2020 at least $60 \%$ of commercial and public buildings in Europe will be equipped with cooling appliances. The residential sector is less often supplied by DC, although this may change as the climate warms and incomes rise [68]. At least $15 \%$ of 
electricity consumption worldwide is used for cooling purposes [69]. Today DC in Europe represents about $2 \%$ of the total cooling market, corresponding to approximately $3 \mathrm{TWh}$ cooling [70]. The market penetration of DC shows great diversity. This market has emerged quite recently and is consequently less developed than DH. However, it has been growing rapidly in the last decade, with a tenfold growth in installed capacity. Although DC is not yet well established in Europe, it is well developed in North America [71]. Solar cooling is a promising technology to be included in DC, as solar energy is widely available and matches the cooling demand well [72].

\subsection{System integration}

The main components comprising a solar DC are: solar collectors, cooling system, distribution network and storage. The overall system performance depends on how the different parts interact. The interaction between solar collector field and cooling system is generally the most critical [73]. In fact, the efficiency of the collector field decreases with operating temperature, while the efficiency of the thermally driven cooling process increases. Differently designed collectors operate at different temperatures, so it is important to match the collector type with the chiller type. Given a certain range of required supply temperature from the chiller, most kinds of solar collectors may find their application in solar cooling. The most commonly used combinations are shown in Table 3 [69,72-76]. In Table 3 the presented $\mathrm{COP}_{\mathrm{N}}$ values are the maximum experimental values found in literature.

Table 3: Typical matching between solar collector types and sorption technologies.

\begin{tabular}{lcccl}
\hline Sorption technology & $\begin{array}{c}\text { Required } \\
\mathbf{T}_{\text {in }}\left[{ }^{\circ} \mathbf{C}\right]\end{array}$ & $\mathbf{T}_{\text {Chill,out }}\left[{ }^{\circ} \mathbf{C}\right]$ & $\mathbf{C O P}_{\mathbf{N}}$ & Solar Technology \\
\cline { 1 - 4 } Absorption & & & & \\
\cline { 1 - 2 } Single effect & $75-90$ & $\mathrm{LiBr}: 4-7$ & 0.7 & Flat-plate \\
Double effect & $120-160$ & $\mathrm{NH}_{3}:<0$ & 1.2 & Evacuated tube, concentrating collector \\
Triple effect & 220 & & 1.7 & Concentrating collector \\
\hline Adsorption & & & & \\
\cline { 1 - 4 } Silica-gel-Water & $<85$ & $0-4$ & 0.6 & Flat-plate \\
Carbon-Methanol & $>120$ & $-12--2$ & 0.4 & Evacuated tube, concentrating collector \\
Carbon-Ammonia & $>150$ & $-10-0$ & 1.19 & Concentrating collector \\
Zeolite-Water & $>200$ & $-8-0$ & 1.6 & Concentrating collector \\
\hline
\end{tabular}

In principle, the high temperatures reached with solar concentrators that occupy a smaller area lead to an increased COP and a reduction of the system cost [72]. Non-concentrating collectors are often used for their low cost [25], although they can only reach temperatures which are compatible with the low efficiency sorption technologies.

Thermal storage can be either a heat energy storage (HES) for the solar heat or a cold energy storage (CES) supplied by the cooling system [72]. Three configurations are possible: CES, HES and CES+HES. The main advantage of the last configuration is the perfect match between demand and cooling generation, and the increase of system performance through a more constant heat supply to the thermally driven chiller, which leads to an optimization of the $\mathrm{COP}_{\text {solar }}[72]$. 
In [77] two different systems for a DHC in Madrid (Spain) are compared through their

577 payback period. The first system comprises three engines of $730 \mathrm{~kW}_{\mathrm{el}}$ and a backup boiler of $578670 \mathrm{~kW}_{\text {heat }}$ as generation system, and two double effect absorption chillers of $1.1 \mathrm{MW}_{\text {cooling }}$ 579 and five backup compression chillers of $1 \mathrm{MW}_{\text {cooling }}$ as cooling system. The payback is 10.6 580 years. The second system comprises $2000 \mathrm{~m}^{2}$ flat plate vacuum collectors, three engines of $581730 \mathrm{~kW}_{\mathrm{el}}$ and a backup boiler of $200 \mathrm{~kW}$ heat as generation system, and a double effect 582 absorption chiller of $3 \mathrm{MW}_{\text {cooling }}$ and a backup chiller of $4 \mathrm{MW}_{\text {cooling }}$ as cooling system. 583 Assuming a 60\% subsidy for the solar collector field, the payback time is 11.6 years.

584 There are an increasing number of large solar cooling systems [25], many of which are 585 installed and operated by ESCos (Energy Service Companies), principally Solid from Austria 586 [78]. However, most of these systems supply single consumers and thus are not strictly solar 587 DC.

\subsection{Example (ParcBit, Spain)}

589 The ParcBit solar district heating and cooling system is located in Mallorca (Spain) and run 590 by Sampol Ingeniería y Obras. This system provides heating and cooling to the University of 591 Balearic Islands and the Innovation centre Parc Bit. The power plant comprises multiple 592 generation systems for heating and cooling, as well as a storage. In Table 4 key figures 593 provided by the operating company are listed.

595 Table 4: Parc Bit main figures.

\begin{tabular}{|c|c|c|c|c|c|c|}
\hline & Element & Technology & Installed Figure & Flow & $\begin{array}{c}\text { Yearly } \\
\text { demand }\end{array}$ & Cost per unit \\
\hline \multirow{4}{*}{ Generation } & IC Motor (2) & Diesel & $2 \times 1.36 \mathrm{MW}_{\mathrm{e}}$ & $76 \mathrm{~m}^{3} / \mathrm{h}$ & $68.1 \%$ & $450 € / \mathrm{kW}$ \\
\hline & Solar Collectors & Flat Plate & $0.7 \mathrm{MW}_{\mathrm{h}}-900 \mathrm{~m}^{2}$ & $35 \mathrm{~m}^{3} / \mathrm{h}$ & $2.4 \%$ & $350 € / \mathrm{m}^{2}$ \\
\hline & Biomass & Wood chip & $1 \mathrm{MWh}$ & $65 \mathrm{~m}^{3} / \mathrm{h}$ & $21.5 \%$ & $600 € / \mathrm{kW}$ \\
\hline & Burner (2) & Diesel & $1.2+0.8 \mathrm{MWh}_{\mathrm{h}}$ & $115 \mathrm{~m}^{3} / \mathrm{h}$ & $8.0 \%$ & $70 € / \mathrm{kW}$ \\
\hline \multirow{4}{*}{ Cooling } & Absorption (2) & Single. Li-Br & $1.3+0.64 \mathrm{MW}_{\mathrm{c}}$ & $180+65 \mathrm{~m}^{3} / \mathrm{h}$ & $43.2 \%$ & $150-300 € / \mathrm{kW}$ \\
\hline & Electric Chiller & Compressor & $1.2 \mathrm{MW}_{\mathrm{c}}$ & $170 \mathrm{~m}^{3} / \mathrm{h}$ & $18.6 \%$ & $55 € / \mathrm{kW}$ \\
\hline & Electric Chiller & Screw & $1.3 \mathrm{MW}_{\mathrm{c}}$ & $155 \mathrm{~m}^{3} / \mathrm{h}$ & $38.2 \%$ & $55 € / \mathrm{kW}$ \\
\hline & Cooling Tower (3) & Open & $3 \times 4 m^{3}$ & $200 \mathrm{~m}^{3} / \mathrm{h}$ & - & $15 € / \mathrm{kW}$ \\
\hline \multirow{2}{*}{ Storage } & Heat Storage & Water & $2 \times 100 \mathrm{~m}^{3}$ & & & $300 € / \mathrm{m}^{3}$ \\
\hline & Cold Storage & Water & $2 \times 100 \mathrm{~m}^{3}$ & & & $300 € / \mathrm{m}^{3}$ \\
\hline \multirow{2}{*}{ Network } & District Heating (4) & Insulated Steel & $2 \times 0.12 \mathrm{~m}^{2}$ & $250 \mathrm{~m}^{3} / \mathrm{h}$ & $9000 \mathrm{MWh}$ & $200 € / \mathrm{m}$ \\
\hline & District Cooling (4) & Insulated Steel & $2 \times 0.33 \mathrm{~m}^{2}$ & $400 \mathrm{~m}^{3} / \mathrm{h}$ & $3000 \mathrm{MW}_{\mathrm{c}}$ & $350 € / \mathrm{m}$ \\
\hline
\end{tabular}

In ParcBit power plant, the connection of the solar collectors has different configurations for 598 summer/winter, allowing the collectors to provide heat to the absorption machine in summer 599 or directly cover the heat demand in winter (Figure 9). The absorption and the screw electric 600 chiller are cooled down by water and both use the same cooling towers, while the 601 compression electric chiller is air cooled. The storage system comprises two cooling tanks and 602 other two tanks for heating. The storage volume is very limited and hence it works more as 603 energy buffer than storage. 


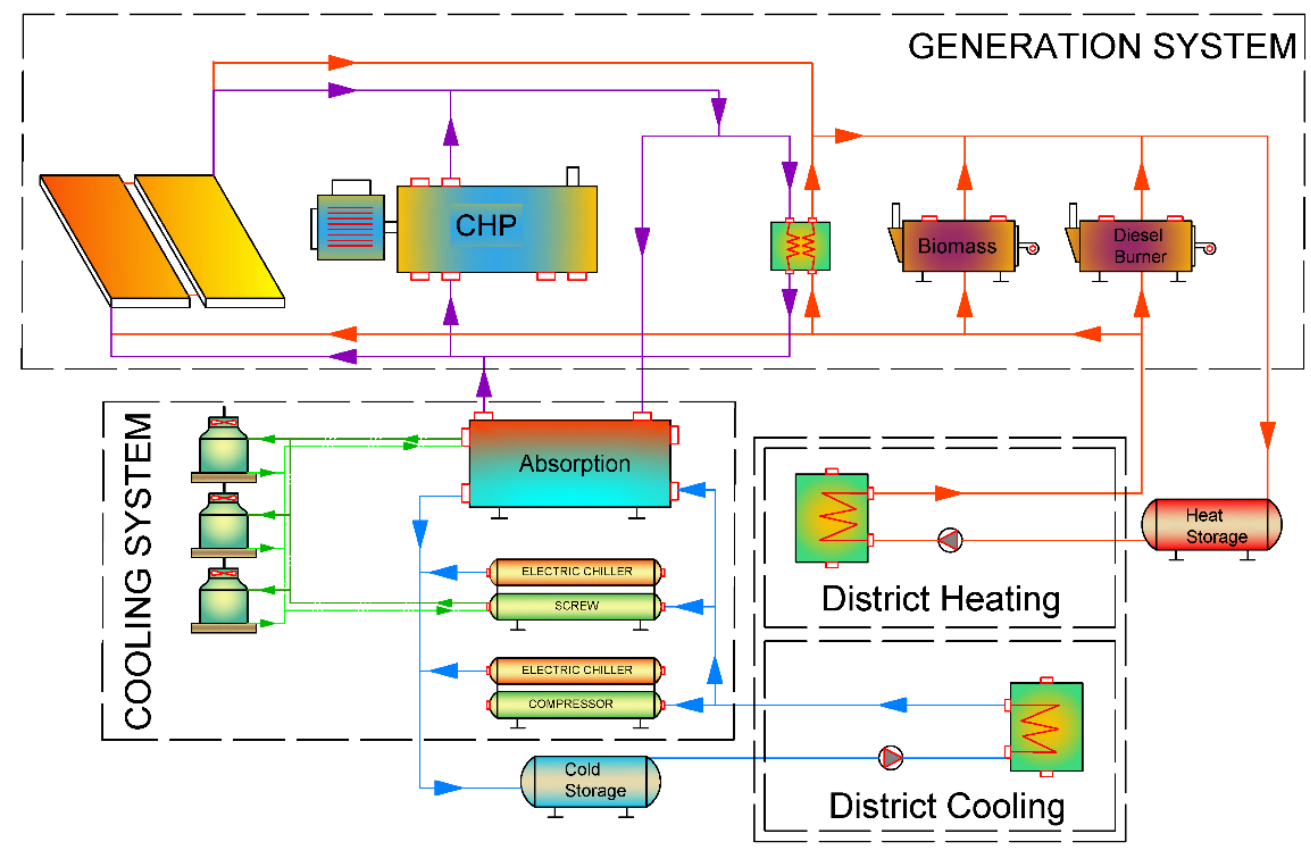

604

605

606

607

608

609

610

611

612

613

Figure 9: Parc Bit power plant hydraulic scheme.

In order to operate the power plant efficiently it is required to forecast accurately the solar generation from the field. To achieve such estimation for ST generation, it is needed to forecast the solar irradiation [79-81] and take into consideration the ageing of the solar collectors [82]. The forecast information can be used on a power plant simulator aiming to improve generation strategies, reduce generation expenses and maximize revenues in generation. The power plant simulator generates strategies by using a decision maker tool [83-85]. This tool supports the plant manager decision process while aims to optimize the cooling energy generation.

\section{SOLAR COLLECTORS}

Solar collectors connected to DH networks are mounted either on the ground or on buildings roofs, depending on availability and cost. These two possibilities are described in the following sections.

\subsection{Ground-mounted collectors}

When the collector area is large and the price of land cheap, the collectors are mounted on the ground, close to the heating plant, which makes the installation easy and economical. This type of solution is commonly adopted in Denmark, but also in Sweden and Austria. Groundmounted collectors are arranged in rows of 10-25 modules in series [8], which are then connected in parallel. In order to maximize the efficiency of the array, its layout should be such that the outlet temperature of every row is the same. Uniform outlet temperatures are achieved when the flow rate in each row is approximately proportional to the row collector 
area. Collector rows having the same composition should be supplied by the same flow rate. Reaching uniform flow distribution in all operating conditions is unrealistic, so an amount of non-uniformity must be accepted. According to the German standard VDI 6002 [86] deviations within $\pm 10 \%$ are acceptable. There are several methods to achieve good flow distribution. One is the adoption of a Tichelmann connection (Figure 10.b), which approximately equalizes the hydraulic resistances of the different rows, but also requires longer pipes and consequently additional cost. Alternatively, it is possible to install mechanical balancing valves (Figure 10.c), which are very effective, but entail higher cost and longer installation time. This is the most common solution adopted in large collector arrays in Denmark. Installing fewer collectors in rows which are farther away (and hence with higher hydraulic resistance) may be coherent with the concept that shorter rows should be supplied with lower flow rates (Figure 10.a). However, this approach requires very careful planning and precise calculation, as later adjustment would be very expensive. Finally, if the pressure drop across the collector rows is much higher than in the supply/return pipes, a sufficiently 641

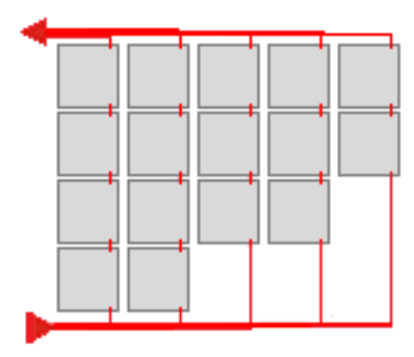

(a)

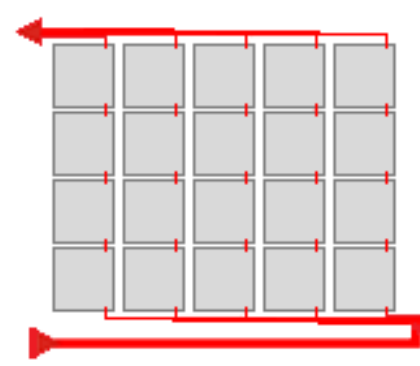

(b)

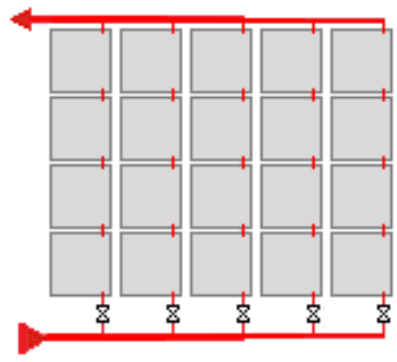

(c)

642 Figure 10: Possible array configurations to achieve uniform outlet temperature (adapted 643 from [87]).

644 The European market of large solar heating systems is dominated by flat plate collectors [24]. 645 These collectors have undergone a strong development during the last years with regard to 646 quality, efficiency increase and cost reduction [82]. The collectors used in large solar installations have areas of $10-15 \mathrm{~m}^{2}$, which make the installation faster and more costeffective. Aluminium strips are commonly used as absorber, because they are easier to handle and cheaper than copper [19], but also steel and copper can be used. Given the large size of the collectors, several absorber pipes are connected in parallel, running from a supply to a return manifold, so to reduce the pressure loss. The collectors may have a polymer foil mounted between absorber and glass cover to decrease convection losses [88]. In some cases both collectors without and with foil are used, the former at the beginning of the row and the latter at the end, so to achieve the most cost-effective row composition [34]. More recently, collectors based on the heat pipe principle have also been proposed for DH applications, as in Vidailhan (France) in 2014 [89]. The collectors used in this installation are based on an aluminium roll bonded heat pipe, inserted in a double wall vacuum glass tube, in

658 order to limit thermal losses and allow high efficiency, even at high operating temperatures. 659 Efficiency between $60 \%$ and $70 \%$ are aimed at for temperatures between $80{ }^{\circ} \mathrm{C}$ and $110{ }^{\circ} \mathrm{C}$ 660 [90]. Additionally, the dry thermal contact between the heat pipe condenser and the main pipe 661 makes installation and maintenance fast and easy. 
662 Depending on the climate, propylene glycol/water mixtures may be used as solar collector 663 fluid to prevent freezing. Additives are also added to avoid corrosion [8]. As higher 664 concentrations of glycol entail poorer fluid properties in terms of specific heat and heat 665 transfer, a lower concentration assuring anti-freezing protection only to a certain extent may 666 be preferred. If the fluid temperature approaches its freezing point, the pump of the solar 667 collector loop starts and the fluid circulates, with or without the input of auxiliary heat.

668 The collector rows are connected in parallel through pre-insulated underground pipes like 669 those used in DH networks. Unlike pipes for DH networks, the collector array pipes need to 670 cope with higher and more frequent temperature variations. To deal with thermal expansion 671 cycles of the pipes without risk of breakage, expansions fittings, such as expansion bellows or 672 lyre loops, are installed. Wires for potential leak tracing can be embedded in the pipe 673 insulation [8].

674 A control strategy using constant flow and a simple on/off controller is normally used in R/R 675 configuration, where the solar heat is transferred to the return pipe of the DH network for 676 preheating purposes. An auxiliary energy source is required downstream to reach the desired 677 supply temperature for the DH network, even during most of the summer. Solar collector 678 arrays built in Denmark between 1988 and 1996 used this control strategy [91]. "Matched 679 flow" principle has become the dominant control method with collector array connected as an $680 \mathrm{R} / \mathrm{S}$ system. Constant outlet temperature is achieved by regulating the flow rate based on the 681 output of a simple collector array model with measured solar radiation, inlet fluid and air 682 temperatures as inputs [91]. The collector array pump starts if one of the following conditions 683 is met:

684

685

686

687

688

689

690

691

692

693

694

695

696

697

698

699

700

701

702
- the temperature at the outlet of the rows is higher than the temperature at the bottom of the buffer tank and/or the feed-in temperature to the DH network by a pre-set value;

- the energy output from the collector field calculated on the basis of measured inlet temperature and weather parameters is higher than a minimum pre-set value.

Due to its large heat capacity, the solar collector loop needs some time before reaching the desired outlet temperature. Hence, in the start-up phase, only the collector array pump is run. The pump on the DH side is turned on only when the temperature from the array is several degrees higher than the temperature on the $\mathrm{DH}$ side. If the solar irradiance is not high enough to reach the DH supply temperature, the water warmed up by the solar heat is mixed with hot water from the auxiliary boilers, which has a higher temperature than the DH requirements. The heat from the solar collector loop is transferred to the DH side loop through large flat plate heat exchangers. To maximize the heat transfer, the water flow rate on the DH side loop is such that an equal heat capacity rate on both sides of the heat exchanger is maintained [92]. The temperature difference across the heat exchanger is usually 3-6 K [8].

On a seasonal basis, the control strategy aims at supplying energy at the supply temperature of the DH in summer time (so that no auxiliary energy is required) and preheating the return of the $\mathrm{DH}$ in winter. The solar heat is transferred to the $\mathrm{DH}$ network whenever possible. If excess heat is produced, this is delivered to the storage. Typical operating temperatures of solar assisted DH networks are about $35^{\circ} \mathrm{C} / 80{ }^{\circ} \mathrm{C}$ [8] (see also Table 1). 


\subsection{Roof-mounted collectors}

The general layout principles for roof-mounted collectors are the same as for ground-mounted collectors (Section 7.1). However, there are a number of practical issues, depending on how the collectors are mounted. The collectors can be mounted either with the same tilt and azimuth as the roof (i.e. integrated in or mounted on top of the roofing material), or using some kind of support. The second option is generally used for flat roofs or if the tilt and azimuth angles desired for the collectors differ from those of the roof. For collector arrays on flat roofs, the design principles are the same as for ground-mounted arrays (Section 7.1). For the first installation type, the roof tilt is often higher than $\sim 15^{\circ}$, which makes access and safety requirements more difficult. This difficult access means that balancing valves are rarely used for ensuring balanced flow in the parallel rows. Collector rows and connecting pipes are designed so that the pressure drop in the rows is much higher than in the pipes. A resulting flow distribution within $10 \%$ of the average flow for all rows can be achieved in this way, so respecting the guidelines of the German standard VDI 6002 [86]. The Tichelmann connection (Figure 10.b) is rare, due to the extra cost. Especially in roof-integrated/mounted collectors, it is important to consider the thermal expansion of the components and design the array, so that the mounting system allows the necessary movement. Flexible pipes between collectors can be used for the same reason.

Difficult access also makes deaeration of the collector loop more problematic. Air in the collector loop can lead to incorrect control of the pump, for example due to air pockets accumulating near the temperature sensor at the top of the collector. Finally, the pressure in the collector loop has to be carefully adapted to the height of the collectors with respect to the lowest point of the loop, to avoid boiling or under-pressure in the loop [93].

Another important aspect for roof-mounted collectors is the aesthetics. These installations are normally visible from other buildings or from the surroundings, so they should harmonize with the rest of the building.

As the roof area of a single building is limited, the complete collector array may be distributed on several buildings. Thus, an important design consideration is whether to connect several of these collector fields together to a common connection to the DH network, or to connect them individually.

\section{STORAGE}

Without storage, the potential solar fraction of a SDH system is very limited due to the limited synchronicity between solar radiation and heat load. Thus, storage is required to bridge the mismatch between the two. Short term storage, normally in the form of steel tank(s), makes it possible to increase the solar fraction of the system up to $15-20 \%$ [8,46]. It can also be used by the auxiliary energy system, being charged in periods of lower demand and discharged to cover peak demand (e.g. in the early morning). As an advantage, the required power of the auxiliary energy system is lower. Higher solar fractions (up to 90\%) are proven to be achievable through a seasonal thermal storage [50]. The storage is charged in summer, when excess solar heat is produced, and discharged whenever it is hotter than the operation temperature of the DH network and the collectors do not produce enough heat. For diurnal storage of solar heat, 50-100 litres water equivalent per square meter of collector area are 
normally used. For seasonal storage with $90 \%$ solar fraction, around $3500-4000 \mathrm{l} / \mathrm{m}^{2}$ are needed [8,50].

Four main types of seasonal storages are currently used: tanks, pits, boreholes and aquifers [94]. However, aquifer storage has mainly been used for heat pump/cooling systems. Both tanks and pit storages can also be used for diurnal storage, while aquifers and boreholes cannot. The choice of storage technology depends on the size of the store, the required heating power, the geological situation and whether the storage is for diurnal or seasonal use [94]. Ellehauge and Pedersen [95] analysed the different storage types and give guidelines on the system integration. As stated in Section 2.3, stores are either located at the main heating plant, or distributed along the DH network. In the existing systems, all the seasonal storages are located centrally, while the distributed storages are nearly always tanks of small volume.

Water tank: Water tanks are most versatile, as they do not require special geological conditions. They are made of steel or concrete walls with steel liner welded on the inner side to assure water and vapour tightness. Tanks are generally well insulated. Having a high height-to-diameter ratio compared to water pits, tanks achieve better stratification, but they are usually smaller for economic reasons, with volumes up to $12,000 \mathrm{~m}^{3}$ [96]. Thermal stratification is enhanced by multiple inlets/outlets placed at different heights, which allow charging/discharging the tank at the right temperature level.

Water pit storages: This technology seems to be the most cost-effective when very large heat capacities are needed. Recently pits with a volume up 200,000 $\mathrm{m}^{3}$ have been built [97]. The present state-of-the-art of this technology comes from experiences made in Denmark in the last years [98-100]. A water pit is conceptually similar to a water tank, but differs in terms of construction, materials and size. Water pits are excavated in the ground and made watertight by welding polymer sheets on the sides and the bottom, without insulation. Due to the large top area, the lid (which also include thick insulation) is not supported, but floats directly on the water. This component is the most critical, both from the construction and economic point of view [95,99,101].

Gravel-water pits: If a pit storage is filled with gravel and water instead of water, the lid construction is simpler, as it can be laid on the gravel. On the other hand, gravel-water stores require a very careful installation, as later maintenance is not possible. They also require larger volumes than water pits, due to the lower heat capacity [11,96,102].

Boreholes: Borehole storages are made by drilling deep vertical holes in the earth/bedrock and filling them with pipe heat exchangers and thermally enhanced grouting material. To reduce thermal losses from the top, an insulation layer and a watertight foil cover the top of the store. As the sides of the store are not insulated, the storage is charged so that the centre is at a higher temperature that the surrounding. This is achieved by connecting the borehole heat exchangers in series from the centre outward. Borehole stores can be easily expanded, adding new holes and pipes at the edges of the existing ones. A drawback is the need for a buffer tank for short term storage due to poor heat exchange capacity rate between pipes and soil [46,50,103-105]. Many borehole storages are used together with a heat pump (Section 3.1), so that the storage temperature and thus the heat losses are lower. However, two seasonal borehole storages have been built with relatively high storage temperatures, one in Sweden [106] and one in Canada [50]. 
Aquifer: In aquifer storages, underground water is extracted from a cold well, heated up and pumped back into the store through a hot well $[107,108]$. This technology is probably the cheapest, but requires very specific hydrogeological conditions, such as water-saturated soil and very little ground water movement. Additionally, permission from water authorities is normally necessary. An example of aquifer storage is located in Rostock [46].

\section{DISCUSSION}

794

795

796

797

798

799

800

801

802

803

804

805

806

807

808

809

810

811

812

813

814

815

816

817

818

819

820

821

822

823

824

825

826

827

828

829

\subsection{Ownership and economy}

Different types of ownership and financing of SDH systems are found in Europe. Large centralized collector fields in Denmark are typically owned and operated by the owner of the DH network, which can be either a public utility or a private cooperative [109]. This represents the least complicated solution, as it requires neither contracts nor feed-in tariffs with third parties. A loan guarantee is usually given by the local municipality, which has almost no risk in doing so, as consumers are bound to a contract obliging them to be customers of the DH utility. The income for the DH utility is then secured and used to pay back the loan [110]. With this guarantee and stable economic boundary conditions, low interest rates can be obtained, resulting in a lower levelized cost of heat supplied by the collector field.

With decentralized feed-in systems owned by parties other than the DH operator, the feed-in tariff has to be agreed with the DH operator who will also define the technical conditions that the system needs to fulfil in order to be allowed to connect and feed in to the DH network. Roof-mounted collector fields can be legally more complicated. The most common solution is that the owner of the building also owns the collectors and sells/buys heat from the DH network according to a contract, like in recent decentralized plants in Sweden [110]. However, there are some cases, for example in Germany, where the utility owns the collectors, mounted on a privately owned building. This kind of combination is possible, but needs to be carefully regulated with an agreement between the two parts to define the respective responsibilities and liabilities [110].

Another possibility is that an ESCo installs and operates the collector field and then sells the solar heat to the DH network or to the building owner (if the collectors are roof-mounted) [111,112]. The ESCo takes the financial risk away from the DH company or the building owner, who only needs to pay according to amount of heat delivered. This solution has been proven to be successful, as utilities and building owners without experience in ST systems may not be willing to accept the risk of the investment, even if the long-term economic feasibility is advantageous. For example, in Austria the company Solid has installed large decentralized solar plants in the town of Graz and most of these are now operated in the form of an ESCo [113].

Although less common, another solution is a co-operative ownership, where the collector array is split and owned by different private people, who receive a yearly dividend. An example is the $454 \mathrm{~m}^{2}$ collector field in Neckarsulm, Germany [110].

In Figure 11 systems are compared as well in terms of Levelised Cost Of Heat (LCOH) based on the results of [114]. The comparison is between solar block heating (SBH) systems roof 
mounted and solar district heating (SDH) ground mounted, comparing at the same time seasonal storage (SS) and diurnal storage (DS). As the LCOH has a dependency on the climate and local conditions, LCOH is shown for both southern european and central-north european regions. The lowest $\mathrm{LCOH}$ is given in southern european regions, ground mounted solar distric heating and diurnal storage.

LCOH Northern and Southern European Climates

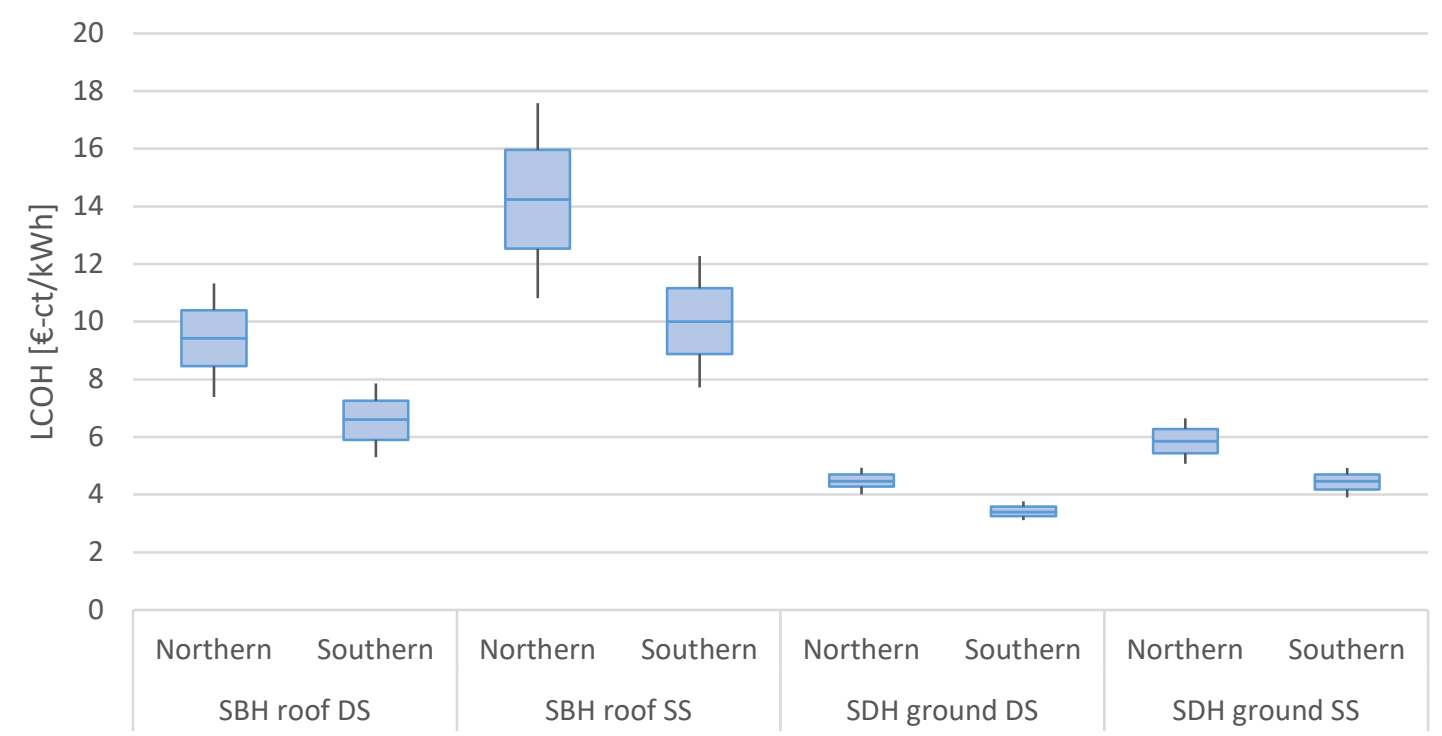

Figure 11: Levelised Cost Of Heat in Northern and Southern European Climates

\subsection{Trends}

In Denmark, the development of large solar collector fields for DH applications has been remarkable in the last years (Figure 12). In 2015, the current largest solar collector field was installed in Vojens, with a collector area of 70,000 $\mathrm{m}^{2}$ and a seasonal water pit storage of $200,000 \mathrm{~m}^{3}$ [24]. This trend is expected to continue in the coming years (Figure 12). In 2016 a $150,000 \mathrm{~m}^{2}$ solar collector field is expected to be completed in Silkeborg [115]. Compared to the period 2014-2016, a milder increase in the installed collector area is expected for 2017, due to some changes in the relevant regulations in Denmark. Solar collector fields connected to DH networks put in operation by the end of 2016 could take part in a trade of energysaving points [116]. This market is similar to carbon emissions trading. Companies reaching their energy saving targets can sell their extra energy-saving points to companies that do not meet their energy saving requirements [117]. The price of these energy savings is not fixed, but depends on the market supply and demand. In the period 2012-2014 the average market price was around 0.04-0.05 €/kWh [118]. The current agreement which allows SDH to be part of this market expires at the end of 2016 and a new one has not yet been set for the coming years. Many DH companies have suspended their plans for solar installations, waiting to see how the situation would evolve, resulting in a slow-down in the expansion of the market as predicted for 2017 (see Figure 12). This shows the sensitivity of the major SDH market to changes in political instruments.

The Danish experience proves that large centralized solar collector fields for DH are a wellestablished technology and DH utilities do not refrain from commissioning increasingly larger 
858 installations. At the same time, it also shows how political decision and economic conditions 859 may play an important role in the spread of well-established technologies in the field of 860 renewable energies.

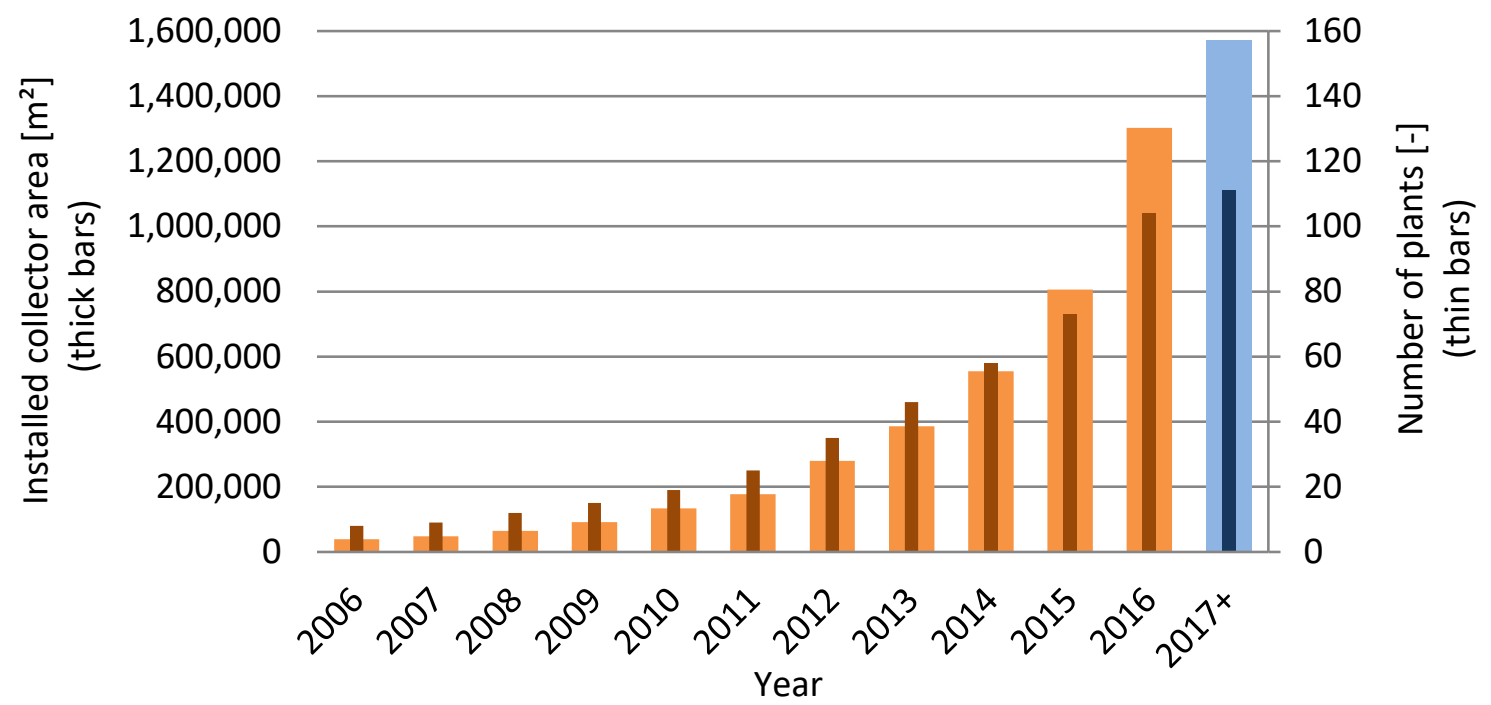

861

862

863

864

865

866

867

868

869

870

871

872

873

874

875

876

Figure 12: Solar district heating in Denmark: installed collector area and number of operating (orange) and upcoming (blue) plants at the end of 2016 [119].

Due to economies of scale, large ground-mounted collector fields are usually characterized by the lowest specific cost, compared to other ST systems. Additionally, enhancements in the production and installation have progressively decreased the investment cost of these systems in the last years, with current prices ranging between $200 €$ and $300 €$ per square meter of collector. Figure 13 shows the trend in investment cost per unit area of collector for large solar collector fields in Denmark in the last 15 years. A remarkable cost reduction has been achieved especially in fields equipped with seasonal storage, due to the improved know-how and to the larger storage volume, which decreases the specific cost.

72 Likewise in solar roof-mounted systems the learning curve and cost reduction of the solar collectors has lowered the specific cost in recent years. Currently the price per square meter ranges between $500 €$ and $1000 €$ depending on the installed area [114]. However the largest registered roof-mounted system cost twice as much as a ground mounted system of the same size. 


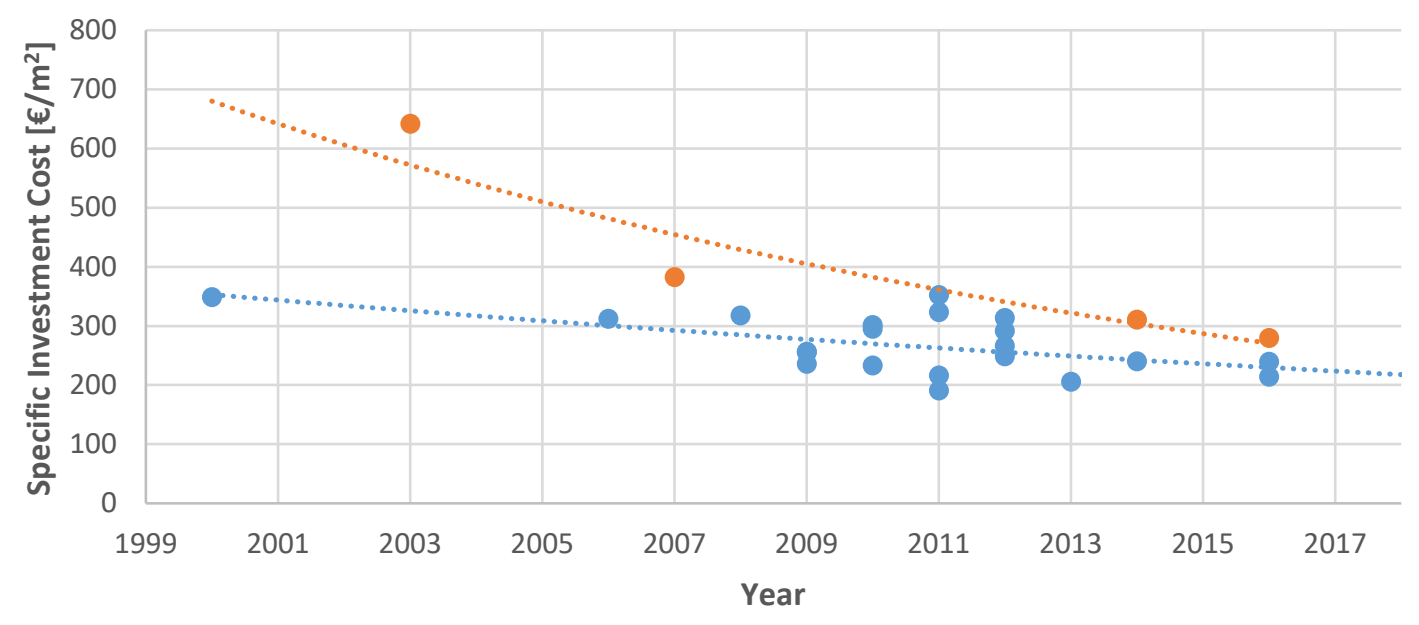

Short term or no storage Long term storage

877

878

879

880

881

882

883

884

886

887

888

889 Table 5. Advantages and Disadvantages of the studied systems

Figure 13: Trend of investment cost per unit area of collector of large centralized systems in Denmark in the last 15 years $[114,120]$.

In the same way due to economies of scale, large thermal storage have usually a low specific cost. In [114] the specific cost of non-pressurised tanks, boreholes and pit thermal storages are presented and compared. The authors derive cost functions for the different thermal storages in terms of the stored volume and show that pit thermal storages have lowest costs.

\section{9.3. System Advantages and Disadvantages}

Four different types of solar district heating and cooling have been presented in this work. In Table 5 the main advantages and disadvantages are shown seeking for comparison.

\begin{tabular}{|c|c|c|}
\hline System & Advantages & Disadvantages and Limitations \\
\hline$\frac{\frac{\pi}{0}}{\frac{\pi}{0}}$ & $\begin{array}{l}\text { Specific cost of solar collectors and stores is lower } \\
\text { due to economy of scale } \\
\text { Faster installation of solar collector field due to } \\
\text { easy accessibility with ground mounted collectors } \\
\text { Possibility of integrating large thermal storage to } \\
\text { increase the solar fraction of the system }\end{array}$ & $\begin{array}{l}\text { Higher transmission losses due distance to } \\
\text { end user } \\
\text { LCOH of competing heat sources are also } \\
\text { lower due to economies of scale and } \\
\text { possibility of CHP } \\
\text { High supply temperatures reduce and limit } \\
\text { solar collectors performance and annual } \\
\text { yield }\end{array}$ \\
\hline 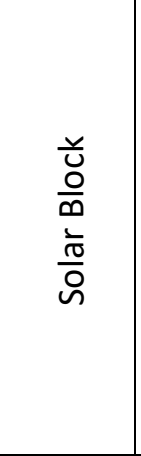 & $\begin{array}{l}\text { High energy harnessing due proximity of the user } \\
\text { to generation } \\
\text { No extra land cost to install solar collector field }\end{array}$ & $\begin{array}{l}\text { Difficult accessibility for installation or } \\
\text { maintenance } \\
\text { Lower density of customers usually entails } \\
\text { higher specific investment costs and } \\
\text { thermal losses as most systems have } \\
\text { buildings with relatively low energy demand } \\
\text { Extra complexity to the overall design } \\
\text { process of a new building area }\end{array}$ \\
\hline
\end{tabular}




\begin{tabular}{|c|c|c|}
\hline 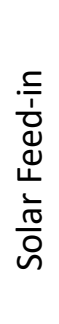 & $\begin{array}{l}\text { Usage of existing infrastructure: Roof tops and DH } \\
\text { network } \\
\text { High energy harnessing due proximity of the user } \\
\text { to generation } \\
\text { Possibility of pre-fabricated systems }\end{array}$ & $\begin{array}{l}\text { Difficult accessibility for installation and } \\
\text { maintenance } \\
\text { Feed-in contract needs to be established } \\
\text { with DH operator and risk of low feed-in } \\
\text { tariffs }\end{array}$ \\
\hline 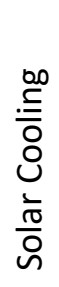 & $\begin{array}{l}\text { Solar availability matches cooling demand } \\
\text { Solar heat can be used for both heating and } \\
\text { providing cooling via an absorption chiller }\end{array}$ & $\begin{array}{l}\text { Absorption chiller requires high heating } \\
\text { temperatures which reduces solar yield and } \\
\text { limits power plant operation temperature } \\
\text { Absorption chiller will be required if not } \\
\text { already included in the system design }\end{array}$ \\
\hline
\end{tabular}

\section{CONCLUSION}

Based on the comprehensive literature review and study cases proposed, the conclusion can be summarized as follows:

- Large scale centralised solar thermal plants for district heating are now fully commercially viable given the right financial boundary conditions, as is the case in Denmark. This has led to a vibrant market, large cost reductions and improvements in field control.

- These systems all have ground mounted collectors, which lead to lower costs than for roof mounted collectors due to the possibility of using larger collectors and a more rational and simpler mounting as well as several other practical issues.

- System integration is very dependent on the individual district heating/cooling network, while the collector field itself is more dependent on ground or roof mounting. Many different configurations can be found in the literature, and no common system design has yet been established. This is especially true for systems with roof mounted collectors, where the collector fields are often distributed on several buildings.

- Seasonal storage costs have decreased significantly in recent years, and there is a trend to use pit storages for this purpose. However, diurnal storage is still dominant in all systems, especially in block heating systems.

- Centralized systems with ground mounted collectors together with seasonal storage have a lower levelized cost of heat than block heating systems with roof mounted collectors and diurnal storage.

- Decentralized, feed-in systems, have become more common but are still not fully commercial and the literature shows that there is not yet a standard design for such installations, with different connection configurations used in different cases.

- Despite the theoretical advantages of solar district cooling, there are very few studies and existing plants g. Most larger solar cooling systems are restricted to a single customer and thus are not district cooling. 
920

921

922

923

924

925

The authors are thankful to the Marie-Curie Actions Initial Training Network (FP7) of the European Union who supported Andersen M., Bava F., Nielsen C.K. and Perez-Mora N. through the SolNet-SHINE program. The authors are also thankful for the support to Lennermo G. whose contribution has been carried out under the auspices of the industrial post-graduate school REESBE (Resource Efficient Energy Systems for the Built Environment), which is financed by the Swedish Knowledge Foundation (KK-stiftelsen).

\section{REFERENCES}

[1] Rezaie B, Rosen M a. District heating and cooling: Review of technology and potential enhancements. Appl Energy 2012;93:2-10. doi:10.1016/j.apenergy.2011.04.020.

[2] Gebremedhin A. Optimal utilisation of heat demand in district heating system-A case study. Renew Sustain Energy Rev 2014;30:230-6. doi:10.1016/j.rser.2013.10.009.

[3] Gang W, Wang S, Xiao F, Gao DC. District cooling systems: Technology integration, system optimization, challenges and opportunities for applications. Renew Sustain Energy Rev 2016;53:253-64. doi:10.1016/j.rser.2015.08.051.

[4] ESTTP PESTT. Solar heating and cooling for a sustainable energy future in Europe renewable energy house. 2007.

[5] Heller A. Solar energy - a realistic option for district heating. Euroheat Power/Fernwarme Int 2001;30:5.

[6] Mauthner F, Weiss W. Solar Heat Worldwide:Markets and Contribution to the Energy Supply. Iea Shc 2013;1. doi:10.1017/CBO9781107415324.004.

[7] FURBO S. Test Procedures for Heat Storages for Solar Heating Systems. Int J Sol Energy 1982;1:419-29. doi:10.1080/01425918208909903.

[8] Windeleff J, Nielsen JE. Solar District Heating in Denmark. Danish Energy Authority \& PlanEnergi; 2014.

[9] Heller A. 15 Years of R\&D in central solar heating in Denmark. Sol ENERGY 2000;69:437-47. doi:10.1016/S0038-092X(00)00118-3.

[10] FISCH N, KÜBLER R. Solar Assisted District Heating -Status of the Projects in Germany. Int J Sol Energy 1997;18:259-70. doi:10.1080/01425919708914322.

[11] Lottner V, Schulz ME, Hahne E. Solar-Assisted District Heating Plants: Status of the German Programme Solarthermie-2000. Sol Energy 2000;69:449-59. doi:10.1016/S0038-092X(00)00125-0.

[12] LUND PD. A Comparative Study of Community Solar Heating Systems for Northern High Latitudes. Int J Sol Energy 1984;2:233-47. doi:10.1080/01425918408909928.

[13] Lund PD, Routti JT, Mäkinen R, Vuorelma H. Simulation studies of the expected performance of Kerava solar village. Int J Energy Res 1983;7:347-57. doi:10.1002/er.4440070406.

[14] Rad FM, Fung AS. Solar community heating and cooling system with borehole thermal energy storage - Review of systems. Renew Sustain Energy Rev 2016;60:1550-61. doi:10.1016/j.rser.2016.03.025.

[15] Nomura T, Akiyama T. High-temperature latent heat storage technology to utilize exergy of solar heat and industrial exhaust heat. Int J Energy Res 2016:240-51. doi:10.1002/er.3611.

[16] Fredriksen S, Werner S. District Heating and Cooling. Lund, Sweden: Studentlitteratur AB; 2013.

[17] Skagestad B, Mildenstein P. District Heating and Cooling Connection Handbook 2002. 
http://www.districtenergy.org/assets/CDEA/Best-Practice/IEA-District-Heating-andCooling-Connection-Handbook.pdf.

[18] Lapillonne B, Pollier K, Samci N. Energy efficiency trends for households in the EU 2015. http://www.odyssee-mure.eu/publications/efficiency-bysector/household/household-eu.pdf.

[19] Dalenbäck J-O, Werner S. Solar District Heating: Market for Solar District Heating 2012. http://solar-district-heating.eu.

[20] Cross Border Bioenergy. EU Handbook: District Heating Markets 2012. http://www.crossborderbioenergy.eu/fileadmin/crossborder/DH_MarketHandbook.pdf.

[21] Dalenbäck J-O, Werner S. Solar District Heating: Boundary Conditions and Market Obstacles 2012. http://solar-district-heating.eu.

[22] Schubert M, Holter C, Soell R. Solar District Heating (SDH): Technologies used in large scale SDH plants in Graz - Operational experiences and further developments. Proc. 12th Int. Symp. Dist. Heat. Cool., Tallinn: 2010, p. 140-2.

[23] Dalenbäck J-O. Ranking List of European Large Scale Solar Heating Plants 2015. http://solar-district-heating.eu/ServicesTools/Plantdatabase.aspx (accessed August 23, 2013).

[24] Mauthner F, Weiss W, Spörk-Dür M. Solar Heat Worldwide: Markets and Contribution to the Energy Supply 2014. 2016.

[25] Dalenbäck J-O. Solar District heating and cooling. vol. 10, 2013, p. 26-9.

[26] Zinko H, Bernestål A, Andersson P-E, Calminder B, Isaksson H. Storskalig solfjärrvärme - generella förstudier etapp 1 (Large scale solar district heating - general feasability studies, stage 1). Stockholm, Sweden: Svensk fjärrvärme; 2002.

[27] Solvarmedata.dk 2015. http://www.solvarmedata.dk/ (accessed August 23, 2016).

[28] Sørensen PA. Solar district heating guidelines: Solar heat combined with other fuels 2012. http://solar-district-heating.eu.

[29] Faninger G. Combined solar-biomass district heating in Austria. Sol Energy 2000;69:425-35. doi:10.1016/S0038-092X(00)00117-1.

[30] Dalenbäck J-O. Large scale solar heating and cooling systems in Europe. In: Goswami DY, Zhao Y, editors. Proc. ISES World Congr. 2007 Sol. Energy Hum. Settl., Beijing (China): Springer Berlin Heidelberg; 2007, p. 799-803. doi:10.1007/978-3-540-759973_151.

[31] Furbo S, Perers B, Bava F. Thermal performance of solar district heating plants in Denmark. Conf. Proc. EuroSun 2014, Aix-Les-Bains (France): 2015. doi:10.18086/eurosun.2014.19.11.

[32] Miedaner O, Pauschinger T. Solar District Heating Guidelines: Categories of solar district heating systems 2012. http://solar-district-heating.eu.

[33] Sørensen PA, Larsen J, Thøgersen L, Andersen JD, Østergaard C, Schmidt T. Boreholes in Brædstrup. 2013.

[34] Bava F, Furbo S, Perers B. Simulation of a solar collector array consisting of two types of solar collectors, with and without convection barrier. Proc. Int. Conf. Sol. Heat. Cool. Build. Ind. SHC 2014, Beijing (China): 2014.

[35] Schubert M. Solar District Heating Guidelines: Decentral integration of ST in DH systems 2012. http://solar-district-heating.eu.

[36] Dalenbäck J-O, Lennermo G, Andersson-Jessen P-E, Kovacs P. Solvärme i fjärrvärmesystem - utvärdering av primärinkopplade system (Solar heat in district heating systems - evaluation of systems with primary connection). Svensk fjärrvärme AB; 2013.

[37] Lennermo G, Lauenburg P, Brand L. Decentralized heat supply in district heating systems - implications of varying differential pressure. 14th Int. Symp. DH Cool., 
[38] Lennermo G, Lauenburg P, Brange L. Små värmekällor (Small heatsources). 2016.

[39] Ben Hassine I, Eicker U. Impact of load structure variation and solar thermal energy integration on an existing district heating network. Appl Therm Eng 2013;50:1437-46. doi:http://dx.doi.org/10.1016/j.applthermaleng.2011.12.037.

[40] Hassine I Ben, Eicker U. Control Aspects of Decentralized Solar Thermal Integration into District Heating Networks. Energy Procedia 2014;48:1055-64. doi:http://dx.doi.org/10.1016/j.egypro.2014.02.120.

[41] Bucar G, Schweyer K, Fink C, Riva R, Neuhäuser M, Meissner E, et al. Dezentrale erneuerbare Energie für bestehende Fernwärmenetze (Decentral renewable energy for existing district heating networks). vol. 78/2006. Bundesministerium für Verkehr, Innovation und Technologie, Austria; 2005.

[42] Dalenbäck J-O. Solar District Heating guidelines: Success factors in Solar District Heating 2010. http://solar-district-heating.eu.

[43] Holter C. Solar district heating taking the full summer load in cities. EuroSun 2010 Conf. Proc., Graz (Austria): 2010.

[44] Paulus C, Papillon P. Substations for Decentralized Solar District Heating: Design, Performance and Energy Cost. Energy Procedia 2014;48:1076-85. doi:http://dx.doi.org/10.1016/j.egypro.2014.02.122.

[45] EBO-Consult. (From large houses to solar houses). vol. 2009-01. Dansk fjernvarmes F\&U konto; 2010.

[46] Bauer D, Marx R, Nußbicker-Lux J, Ochs F, Heidemann W, Muller-Steinhagen H. German central solar heating plants with seasonal heat storage. Sol Energy 2010;84:612-23. doi:10.1016/j.solener.2009.05.013.

[47] Gulliksson H. Närvärme med biobränslen: Vägledning från idé till färdig anläggning (Guideline from idea to finished plant establishment). Energimyndigheten; 2005.

[48] Dalenbäck J-O. Central solar heating plants with seasonal storage: status report. Swedish Council for Building Research; 1990.

[49] Schmidt T, Mangold D, Müller-Steinhagen H. Central solar heating plants with seasonal storage in Germany. Sol Energy 2004;76:165-74.

[50] Sibbitt B, McClenahan D, Djebbar R, Thornton J, Wong B, Carriere J, et al. The performance of a high solar fraction seasonal storage district heating system - Five years of operation. Energy Procedia 2012;30:856-65. doi:10.1016/j.egypro.2012.11.097.

[51] Bodmann M, Fisch MN. Betriebserfahrungen der solar unterstützten Nahwärmeversorgung in Hannover, Steinfurt und Hamburg (Operational experience from solar assisted block-heating supply in Hannover, Steinfurt and Hamburg). OTTI 2003;13:365-70.

[52] Dahm J. Small district heating systems. Chalmers University of Technology, 1999.

[53] Dalenback JO. Solar Heating with Seasonal Storage - Some Aspects of the Design and Evaluation of Systems with Water Storage. Chalmers University of Technology, 1993.

[54] Zinko H. Grudis-tekniken för värmegles fjärrvärme (The GRUDIS technique for low heat density district heating) 2004.

[55] Münster E, Olesen GB. Praktisk demonstration af pulsfjernvarme kombineret med solvarme til lavenergibyggeri (Practical demonstration of pulse district heating in combination with solar heat for low energy buildings). PlanEnergi, Dansk Fjernvarme; 2012.

[56] Lundgren J, Hermansson R. Solar assisted small-scale biomass district heating system in the northern part of Sweden. Int J Green Energy 2004;1:467-82. doi:10.1081/GE200038715. 
1065

1066

1067

1068

1069

1070

1071

1072

1073

1074

1075

1076

1077

1078

1079

1080

1081

1082

1083

1084

1085

1086

1087

1088

1089

1090

1091

1092

1093

1094

1095

1096

1097

1098

1099

1100

1101

1102

1103

1104

1105

1106

1107

1108

1109

1110

1111

1112

1113

1114

[57] Hahne E. Solare Nahwärme-Ein Leitfaden für die Praxis (Solar block-heating - a practical handbook). Köln: TÜV-Verlag; 1998.

[58] Fink C, Riva R, Heimrath R, Halmdiest C, Kaufmann H. Mosolnet, Endbericht zum gleichnamigen Projekt in der Forschungsausschreibung „Haus der Zukunft“ im Auftrag des BMVIT (Summary of the project with the name listed in the research call „The house of the future“ on assignment from BMVIT). Gleisdorf, Austria: AEE Intec, Gleisdorf; 2007.

[59] Mahler B, Fisch MN, Weiß W. Large scale solar heating systems for housing developments. EuroSun 2000 Conf. Proc., Copenhagen (Denmark): 2000.

[60] Beckenbauer D, Brandmayr S, Zörner W. Simulatoin study for the solar retrofitting of a district heating system. Conf. Proc. EuroSun 2014, Aix-Les-Bains (France): 2014.

[61] Nielsen C, Haegermark M, Dalenbäck JO. Analysis of a Novel Solar District Heating System. Conf. Proc. EuroSun 2014, Aix-Les-Bains (France): 2014. doi:urn:nbn:se:du15517.

[62] Chow TT, Fong KF, Chan a. LS, Yau R, Au WH, Cheng V. Energy modelling of district cooling system for new urban development. Energy Build 2004;36:1153-62. doi:10.1016/j.enbuild.2004.04.002.

[63] Perez-Mora N, Martinez-Moll V, Canals V. DHC Load Management Using Demand Forecast. Energy Procedia 2016;91:557-66. doi:10.1016/j.egypro.2016.06.198.

[64] Ortiz M, Barsun H, He H, Vorobieff P, Mammoli a. Modeling of a solar-assisted HVAC system with thermal storage. Energy Build 2010;42:500-9. doi:10.1016/j.enbuild.2009.10.019.

[65] Söderman J. Optimisation of structure and operation of district cooling networks in urban regions. Appl Therm Eng 2007;27:2665-76. doi:10.1016/j.applthermaleng.2007.05.004.

[66] Lin F, Yi J, Weixing Y, Xuzhong Q. Influence of supply and return water temperatures on the energy consumption of a district cooling system. Appl Therm Eng 2001;21:51121. doi:10.1016/S1359-4311(00)00046-6.

[67] Shimoda Y, Nagota T, Isayama N, Mizuno M. Verification of energy efficiency of district heating and cooling system by simulation considering design and operation parameters. Build Environ 2008;43:569-77. doi:10.1016/j.buildenv.2006.03.017.

[68] Andrews D, Pardo-garcia N, Krook-Riekkola A, Tzimas E, Serpa J, Carlsson J, et al. Background Report on EU-27 District Heating and Cooling Potentials , Barriers , Best Practice and Measures of Promotion Contact information. 2012. doi:10.2790/47209.

[69] Fan Y, Luo L, Souyri B. Review of solar sorption refrigeration technologies: Development and applications. Renew Sustain Energy Rev 2007;11:1758-75. doi:10.1016/j.rser.2006.01.007.

[70] Thorsen JE. District Heating \& Cooling a vision towards 2020 - 2030 - 2050. 34th Euroheat Power Congr., Venice (Italy): 2009.

[71] Poredos A, Kitanovski A. District heating and cooling for efficient energy supply. 2011 Int Conf Electr Control Eng 2011:5238-41. doi:10.1109/ICECENG.2011.6058201.

[72] Chidambaram L a., Ramana a. S, Kamaraj G, Velraj R. Review of solar cooling methods and thermal storage options. Renew Sustain Energy Rev 2011;15:3220-8. doi:10.1016/j.rser.2011.04.018.

[73] Casals XG. Solar absorption cooling in Spain: Perspectives and outcomes from the simulation of recent installations. Renew Energy 2006;31:1371-89. doi:10.1016/j.renene.2005.07.002.

[74] Grossman G. Solar-powered systems for cooling, dehumidification and airconditioning. Sol Energy 2002;72:53-62. doi:10.1016/S0038-092X(01)00090-1.

[75] Fernandes MS, Brites GJVN, Costa JJ, Gaspar a. R, Costa V a F. Review and future 
trends of solar adsorption refrigeration systems. Renew Sustain Energy Rev 2014;39:102-23. doi:10.1016/j.rser.2014.07.081.

[76] Wang RZ, Oliveira RG. Adsorption refrigeration-An efficient way to make good use of waste heat and solar energy. Prog Energy Combust Sci 2006;32:424-58. doi:10.1016/j.pecs.2006.01.002.

[77] Rodriguez-Aumente P a., Rodriguez-Hidalgo MDC, Nogueira JI, Lecuona A, Venegas MDC. District heating and cooling for business buildings in Madrid. Appl Therm Eng 2013;50:1496-503. doi:10.1016/j.applthermaleng.2011.11.036.

[78] Holter C. Successful large scale projects on solar cooling - energetic and economic performance. 6th Int. Conf. Sol. Air-Conditioning, Rome (Italy): 2015.

[79] Perez-Mora N, Canals V, Martinez-Moll V. Short-Term Spanish Aggregated Solar Energy Forecast. 13th Int. Work. Artif. Neural Networks, IWANN 2015, Palma de Mallorca (Spain): 2015, p. 307-19. doi:10.1007/978-3-319-19222-2_26.

[80] Perez-Mora N, Martinez-Moll V, Canals V. Spanish Renewable Energy Generation Short-Term Forecast. Proc. ISES Sol. World Congr. 2015, Freiburg, Germany: International Solar Energy Society; 2016, p. 1-12. doi:10.18086/swc.2015.07.10.

[81] Alomar ML, Canals V, Perez-Mora N, Martínez-Moll V, Rosselló JL. FPGA-Based Stochastic Echo State Networks for Time-Series Forecasting. Comput Intell Neurosci 2016;2016:1-14. doi:10.1155/2016/3917892.

[82] Fan J, Chen Z, Furbo S, Perers B, Karlsson B. Efficiency and lifetime of solar collectors for solar heating plants. Proc ISES Sol World Congr 2009 Renew Energy Shap Our Futur 2009:331-40.

[83] Carpaneto E, Lazzeroni P, Repetto M. Optimal integration of solar energy in a district heating network. Renew Energy 2015;75:714-21. doi:http://dx.doi.org/10.1016/j.renene.2014.10.055.

[84] Perez-Mora N, Lazzeroni P, Repetto M. XEMS13: An Hybrid-Energy Generation Management System. IEEE eXpress 2016.

[85] Perez-Mora N, Lazzeroni P, Martinez-Moll V, Repetto M. Optimal management of a complex DHC plant. Energy Convers Manag 2017. doi:10.1016/j.enconman.2017.05.002.

[86] VDI. VDI-Richtlinie 6002 Blatt 1: Solare Trinkwassererwärmung - Allge-meine Grundlagen, Systemtechnik und Anwendung im Wohnungsbau (VDI guideline 6002 leaflet 1: Solar drinkingwater (alt. domestic hot water) preparation - Basic principles, systems technology a. 2004.

[87] Knabl S, Fink C, Ohnewein P, Mauthner F, Hausner R. Requirements and guidelines for collector loop installation. Deliv. IEA-SHC Task 45 Large scale Sol. Heat. Cool. Syst., IEA-SHC; 2014.

[88] Bava F, Furbo S. Comparative test of two large solar collectors for solar field application. Proc. EuroSun 2014 Conf., Aix-Les-Bains (France): International Solar Energy Society (ISES); 2014.

[89] SDH - Solar District Heating. The first solar district heating plant in France is in operation 2014. http://www.solar-districtheating.eu/NewsEvents/News/tabid/68/CategoryID/50/ArticleId/403/The-first-solardistrict-heating-plant-in-France-is-in-operation.aspx (accessed June 22, 2015).

[90] Charles P, Kazmarek F, Lesch T. Solar collectors for districh heating using the rollbond technology. Conf. Proc. EuroSun 2014, Aix-Les-Bains (France): 2014.

[91] Heller A. Large Scale Solar Heating: Evaluation, Modelling and Designing. Technical University of Denmark, 2000.

[92] Nielsen JE, Trier D. Guaranteed power output. Deliv. IEA-SHC Task 45 Large scale Sol. Heat. Cool. Syst., IEA-SHC; 2014. 
[93] Thür A, Letz T, Pradier G, Papillon P, Cholin X, Albaric M, et al. D2.3: Guidelines for Design and Dimensioning. EU Projekt Combisol; 2011.

[94] Schmidt T, Miedaner O. Solar district heating guidelines: Storage 2012. http://solardistrict-heating.eu.

[95] Ellehauge K, Pedersen TE. Solar heat storages in district heating networks. 2007. doi:10.1016/S1474-4422(07)70239-9.

[96] Novo A V., Bayon JR, Castro-Fresno D, Rodriguez-Hernandez J. Review of seasonal heat storage in large basins: Water tanks and gravel-water pits. Appl Energy 2010;87:390-7. doi:10.1016/j.apenergy.2009.06.033.

[97] Dyrelund A. World largest thermal pit storage in Vojens 2014. https://stateofgreen.com/en/profiles/ramboll/solutions/world-largest-thermal-pitstorage-in-vojens.

[98] PlanEnergi. Sunstore 3. Fase 1: Projektering og udbud (Sunstore 3, Phase 1: Project planning and tendering). 2011.

[99] Sørensen PA, Jensen MV, From N. Smart district heating using the SUNSTORE concept. Strojarstvo 2012;54:455-61.

[100] Jensen MV. Seasonal pit heat storages - Guidelines for materials and construction. Deliv. IEA-SHC Task 45 Large scale Sol. Heat. Cool. Syst., IEA-SHC; 2014.

[101] Heller A. Investigation on floating lid construction pit water storage Ottrupgaard, Denmark. 1997.

[102] Pfeil M, Koch H. High Performance - Low cost gravel / water storage pit. Sol Energy 2000;69:461-7.

[103] Heier J, Bales C, Martin V. Combining thermal energy storage with buildings - a review. Renew Sustain Energy Rev 2015;42:1305-25. doi:10.1016/j.rser.2014.11.031.

[104] Pinel P, Cruickshank C a., Beausoleil-Morrison I, Wills A. A review of available methods for seasonal storage of solar thermal energy in residential applications. Renew Sustain Energy Rev 2011;15:3341-59. doi:10.1016/j.rser.2011.04.013.

[105] Sibbitt B, McClenahan D. Seasonal Borehole Thermal Energy Storage - Guidelines for design and construction. Deliv. IEA-SHC Task 45 Large scale Sol. Heat. Cool. Syst., IEA-SHC; 2015.

[106] Lundh M, Dalenback JO. Swedish solar heated residential area with seasonal storage in rock: Initial evaluation. Renew Energy 2008;33:703-11.

[107] Lee KS. A Review on Concepts, Applications, and Models of Aquifer Thermal Energy Storage Systems. Energies 2010;3:1320-34. doi:10.3390/en3061320.

[108] Dincer I, Rosen MA. Thermal Energy Storage: Systems and Applications. 2nd ed. New York: Jonh Wiley \& Sons; 2002.

[109] Tao H. Large Scale Solar District Heating Systems: A Handbook and practical guide. 2014.

[110] Sørensen PA. Solar District Heating Guidelines: Ownership and financing 2012. http://solar-district-heating.eu.

[111] Olsacher N, Holter C. Solid invest - the civic participation-model for solar thermal plants. SDH 2014.

[112] Putz S. ESCo models - General description. Deliv. IEA-SHC Task 45 Large scale Sol. Heat. Cool. Syst., IEA-SHC; 2015.

[113] Putz S. ESCo services, best practise example: Wasserwerk Andritz, Graz, Austria. Deliv. IEA-SHC Task 45 Large scale Sol. Heat. Cool. Syst., IEA-SHC; 2015.

[114] Mauthner F. Technology and demonstrators. Gleisdorf, Austria: 2016.

[115] EnergySupply. Danmarks største solenergianlæg på vej ved Silkeborg (Denmarks largest solar energy plant to be completed in Silkeborg 2016) 2016. http://www.energysupply.dk/article/view/235192/ (accessed February 4, 2016). 
1215

1216

1217

1218

1219

1220

1221

1222

1223

1224

1225

1226

1227

1228

[116] Danish Energy Agency. Energiselskabernes energispareindsats mellem klima-, energiog bygningsministeren og net- og distributionsselskaberne inden for el, naturgas, fjernvarme og olie repræsenteret ved Dansk Energi HMN Naturgas, DONG Gas Distribution, Naturgas Fyn Distribution 2012.

[117] Danish Energy Agency. Energiselskabernes spareindsats (The energy companies savings effort 2016) 2016. http://www.ens.dk/forbrug-besparelser/energiselskabernesspareindsats.

[118] Danish Energy Agency. Benchmarking 2014. http://www.ens.dk/forbrugbesparelser/energiselskabernes-spareindsats/aftalegrundlag-kontrolresultater/benchmarking.

[119] Trier D. Personal communication with D. Trier (PlanEnergi) 2016.

[120] Nielsen JE. Personal communication with J.E. Nielsen (PlanEnergi). Data from Solvarmedata website 2015. 